\title{
Ammonia-Ethanol-Water Pretreatment of Wheat Straw for Facilitating Enzymatic Saccharification Integrated with the Preparation of Submicron Lignin Spheres
}

\begin{abstract}
Xihui Zhang, ${ }^{\text {ab, }}{ }^{1}$ Guang Yu, ${ }^{\text {b, }}$ Xiaoyan Feng, ${ }^{\mathrm{b}}$ Zhenqiu Li, ${ }^{\mathrm{a}, *}$ Bin Li, ${ }^{\mathrm{b}, *}$ and Qiu Cui ${ }^{\mathrm{b}}$
Ammonia-ethanol-water (AEW) pretreatment was adopted to treat wheat straw for ameliorating saccharification with the integrated preparation of submicron lignin spheres (SLS). Results showed that AEW pretreatment could remove $77 \%$ of lignin and $90 \%$ of extractives, thus increasing specific surface area and porosity of the substrate and finally enhancing the release of fermentable sugars in saccharification. Under the optimal pretreatment conditions $\left(170{ }^{\circ} \mathrm{C}\right.$ for $2 \mathrm{~h}$, ethanol concentration $55 \%(\mathrm{v} / \mathrm{v})$, ammonia concentration $7.5 \mathrm{wt} \%$ ), the final total sugar yield reached $81.7 \%$ after pretreatment and saccharification, which was 2.25 times higher compared to the conventional ethanol organosolv pretreatment. Moreover, washing could be excluded for AEW-pretreated wheat straw before saccharification, and both ethanol and ammonia could be readily recovered and reused, making the AEW pretreatment clean and sustainable. In addition, SLS with hollow structure and average diameter of $161.2 \pm 53.6 \mathrm{~nm}$ were fabricated using the fractionated lignin, which could offset the overall cost of AEW pretreatment.
\end{abstract}

Keywords: Ammonia-ethanol-water pretreatment; Enzymatic saccharification; Wheat straw; Submicron lignin spheres; Biorefinery

Contact information: a: College of Marine Science and Biological Engineering, Qingdao University of Science \& Technology, Qingdao 266400, China; b: CAS Key Laboratory of Biofuels, Shandong Provincial Key Laboratory of Synthetic Biology, Shandong Engineering Laboratory of Single Cell Oil, Dalian National Laboratory for Clean Energy, Qingdao Institute of Bioenergy and Bioprocess Technology, Chinese Academy of Sciences, Qingdao, 266101, China; ${ }^{1}$ : Both authors contributed equally to this work

*Corresponding authors: lizhenqiu@qust.edu.cn; libin@qibebt.ac.cn

\section{INTRODUCTION}

The excessive use of fossil fuels is leading to a severe energy and environmental crisis around the world (Ding et al. 2012). Thus, the utilization of lignocelluloses has attracted increased attention, as plants can fix $\mathrm{CO}_{2}$ by photosynthesis and produce biomass (Xu et al. 2016). The annual production of lignocelluloses is estimated to be over 200 billion tons on earth (Hu and Ragauskas 2012). Hence, it is of crucial importance to make better use of the abundant lignocelluloses, particularly in the case of agricultural wastes (e.g., wheat straw), to protect the environment, avoid waste of cellulosic materials, and promote the sustainable development of human society.

The cell wall of lignocellulose is mainly composed of cellulose, hemicellulose, and lignin. Cellulose (glucan) as a linear homo-polymer is present as semicrystalline elementary fibrils, while hemicelluloses are hetero-polysaccharides, consisting of main chains (e.g., xylan) and branched side groups. Both cellulose and hemicelluloses are the sources of fermentable sugars. Lignin is an amorphous biopolymer of phenylpropanoids closely associated with hemicelluloses (Sixta 2006). In plant cell walls, cellulose fibrils 
that play a role of skeleton support are tightly covered by hemicellulose-lignin matrix, and this well evolved structure functions just like a strong reinforced concrete structure (Zhu et al. 2016), which provides a robust natural recalcitrance against outside attack. Thus, in conversion of lignocelluloses to cellulosic ethanol or chemicals, pretreatment is an indispensable step to break the natural resistance of lignocelluloses as a means of facilitating sugar release in downstream saccharification (Sun et al. 2016; Li et al. 2017).

To obtain a high yield of fermentable sugars, lignin removal is usually a priority strategy because it can rupture the physical barrier of lignin to cellulose and reduce the nonproductive absorption of lignin to enzymes (Mosier et al. 2005). As reported, many pretreatments can selectively remove lignin, such as alkali-based pretreatment, biological methods, sulfite pretreatment, deep eutectic solvents pretreatment, and organosolv pretreatment (Agbor et al. 2011; Liu et al. 2019). Among these methods, organosolv pretreatment using ethanol is considered to be a very promising pretreatment due to its inherent advantages, such as good lignin solubility, high retention of available carbohydrates, coproduction of high-purity lignin, low cost of solvent, lack of toxicity, good miscibility of ethanol with water, and the easy recovery and reuse of the solvent (Zhou et al. 2018). In ethanol organosolv pretreatment, lignin dissolution is catalyzed by acetic acid (generated from the hydrolysis of acetyl groups on hemicelluloses) mainly through the cleavage of $\beta-\mathrm{O}-4$ linkage in lignins (Wen et al. 2013), and simultaneously, part of hemicellulose is degraded (Guo et al. 2015). Ethanol is beneficial to the penetration of reagent to plant tissue, and also the dissolution of degraded lignin fragments (Zhou et al. 2018). Yet, the lignin removal of ethanol organosolv pretreatment is typically less than $70 \%$ (Hallac et al. 2010). Hence, acid, inorganic salts, or alkali agents can be added in ethanol organosolv pretreatment to enhance delignification and reduce pretreatment severity. Either inorganic (e.g., sulfuric acid) (Sidiras and Koukios 2004) or organic acids (e.g., formic acid) (Li et al. 2016) can be used, but acids can cause severe degradation of hemicelluloses, generation of inhibitors, lignin condensation and precipitation, equipment corrosion, and generation of acid wastewater (Tarasov et al. 2018). Replacing acid with inorganic salts (e.g., $\mathrm{FeCl}_{3}, \mathrm{MgCl}_{2}$ ) can cause less corrosion and less degradation of hemicellulose in ethanol pretreatment, and these salts could be easily recycled (Huijgen $e t$ al. 2011). However, the use of metal salts might complicate process control and affect the purity of separated lignin. As for alkali agents, both inorganic (e.g., $\mathrm{NaOH})$ and organic base (e.g., diethylamine, ethylenediamine) can be used to promote lignin removal in ethanol pretreatment because alkali can efficiently break the linkages of lignin subunits and the crosslinking bonds between carbohydrates and lignin (Xu et al. 2016), and hence the delignification can reach up to over 80\% (Mesa et al. 2011; Tang et al. 2017). In contrast to other bases, ammonia is a promising agent, because it is inexpensive, easily available, non-corrosive, non-polluting, miscible with water and ethanol, and easier to be recovered and reused (Hashemi et al. 2019). Additionally, the residual ammonia in pretreated substrate as the $\mathrm{N}$ source is beneficial to downstream fermentation (Kim et al. 2003). Thus, ammonia is expected be a suitable alkaline reagent which could be used to enhance lignin removal in ethanol organosolv pretreatment. However, ammonia-ethanol-water (AEW, ammonia-assisted ethanol) pretreatment of lignocellulose for improving enzymatic hydrolysis is very little reported. Only Park and Phillips (1988) found that the enzymatic susceptibility of poplar was increased approximately 6-fold after ammonia-assisted ethanol organosolv pretreatment in comparison with the untreated poplar.

On the other hand, lignin valorization is of vital importance to increase the economic feasibility of the entire process for lignocellulose conversion (Luo et al. 2020; 
Mei et al. 2020). Lignin nano-/micron-spheres are relatively new biomaterials that can be potentially used as fillers in composites (Nair et al. 2014), carriers for controlled release of agricultural actives or drugs (Sameni et al. 2018), functional building blocks, etc., and they can be fabricated using different methods (e.g., self-assembly, homogenization) through simple chemical or mechanical mechanisms with different lignin sources (e.g., alkali lignin, organosolv lignin) (Zhao et al. 2016). However, the preparation of submicron lignin spheres (SLS) derived from AEW pretreatment has not been reported.

Therefore, in this work, AEW pretreatment was used to treat wheat straw, and the impact of pretreatment conditions on fermentable sugar release of saccharification and feature changes of the pretreated wheat straw were comprehensively investigated. It is expected that the addition of ammonia in ethanol organosolv pretreatment could efficiently enhance the pretreatment effectiveness of wheat straw. Also, both ethanol and ammonia could be readily recovered and reused, which could make the pretreatment process clean. Thus, the recovery of ethanol and ammonia were evaluated in this work. Most importantly, compared to other alkali reagents, ammonia is relatively safe to environment, and the use of ammonia will not introduce salt ions to pretreatment system, and the separated lignin would have a high purity. In addition, the preparation and characterization of SLS using the fractionated lignin from AEW pretreatment were conducted for the first time. The fabrication of SLS can valorize lignin, thus offsetting the overall process cost of AEW pretreatment.

\section{EXPERIMENTAL}

\section{Materials}

Wheat straw was collected in the summer of 2018 from Weifang of Shandong province, China. As tested following the National Renewable Energy Laboratory (NREL) analytical procedures (Sluiter et al. 2008), the native wheat straw contained $30.3 \pm 0.2 \%$ of glucan, $13.5 \pm 0.1 \%$ of xylan, $1.0 \pm 0.1 \%$ of arabinan, $0.7 \pm 0.1 \%$ of acetyls, $25.1 \pm 0.3 \%$ of lignin (acid soluble lignin + acid insoluble lignin), $14.4 \pm 0.7 \%$ of extractives (hot water extractives + ethanol extractives), and $13.6 \pm 0.1 \%$ of ash. Before pretreatment, the wheat straw with water content of $66.5 \%$ was pulverized by a pilot twin screw extrusion machine (manufactured by Tianzheng Screening Pulping Equipment Co., Ltd., Hebei, China) with the maximum throughput of $200 \mathrm{~kg} / \mathrm{h}$ (Liu et al. 2013). The extrusion duration of wheat straw was only about 30 seconds, and just one pass was conducted to avoid over damage of wheat straw. The pulverized wheat straw with the particle size less than $2 \mathrm{~cm}$ in length was stored in a sealed plastic bag in a cold room at $4{ }^{\circ} \mathrm{C}$.

All analytical-grade chemicals, including aqueous ammonia (25 wt\%), ethanol (99.5 wt\%), and others, were purchased from Sinopharm Chemical Reagent Co., Ltd. (Shanghai, China) and used as received. The cellulase enzyme used for enzymatic hydrolysis was supplied by Qingdao Vland Biotech Inc. (Qingdao, China, a local supplier) and the activity of cellulase was $86 \mathrm{FPU} / \mathrm{mL}(80 \mathrm{mg}$ protein/mL) as measured by the standard method (Ghose 1987).

\section{Methods}

The AEW pretreatment

The AEW pretreatment of wheat straw was performed in a $15-\mathrm{L}$ stainless steel reactor (PL1-00; Xianyang TEST Equipment Co., Ltd., Xianyang, China) equipped with 
four small cooking bombs inside, and the volume of each bomb was $1 \mathrm{~L}$. In this case, four parallel pretreatment experiments took place simultaneously, and the rotational speed of the reactor was $1 \mathrm{rpm}$. For each pretreatment, $50 \mathrm{~g}$ of wheat straw (based on the dry weight) was used, and the pretreatment was implemented under the certain experiment conditions with the liquid-to-solid ratio of $8(\mathrm{w} / \mathrm{w})$. After pretreatment, the cooking bombs were immediately cooled with cold running water. Then, the spent liquor was squeezed out using a 500-mesh washing bag and collected in a cold trap apparatus in a fume hood. Subsequently, the spent liquor was concentrated after recovery of ammonia and ethanol with rotary evaporation, and then sulfuric acid was added to the concentrated spent liquor until the $\mathrm{pH}$ was adjusted to 3 to get the precipitated lignin (named as P-lignin), which was further purified by washing with deionized water. For comparison, the lignin sample (referred as D-lignin) was also collected by direct drying of the concentrated spent liquor and then followed by washing with deionized water. The solid fraction after AEW pretreatment was first washed once with ethanol $\left(55 \%\right.$, v/v) at $50{ }^{\circ} \mathrm{C}$ and then washed with deionized water at $50{ }^{\circ} \mathrm{C}$ to neutral $\mathrm{pH}$. For comparison, the unwashed solid samples after pretreatment and phase separation were also collected. Finally, both the washed and unwashed samples were stored at $4{ }^{\circ} \mathrm{C}$ for further tests.

In pretreatment experiments, key factors of ethanol concentration ( 0 to $78 \%, \mathrm{v} / \mathrm{v})$, ammonia dosage ( 0 to $100 \mathrm{wt} \%, \mathrm{NH}_{3}$ dosage was based on the dry weight of wheat straw), and energy input were varied to optimize the process and check the effectiveness of pretreatment. When other pretreatment conditions were fixed, energy input can be represented as $\mathrm{H}$-factor, which combines pretreatment time and temperature into a unique variable. This single variable is traditionally used in the pulping industry to indicate the extent of cooking reaction, and it can also be used to evaluate pretreatment (Vergara et al. 2018). The H-factor is calculated by the Eq. 1 (Vroom 1957),

$$
H=\int_{0}^{t} e^{\left(43.2-\frac{16115}{T}\right)} d t
$$

where $T$ is the pretreatment temperature $(\mathrm{K})$, and $t$ is the pretreatment time (h) at $T$. The designed energy input and the calculated values of corresponding $\mathrm{H}$-factors are listed in Table 1.

Table 1. Energy Input and the Corresponding $\mathrm{H}$-factor for AEW Pretreatment

\begin{tabular}{|c|c|c|}
\hline Pretreatment Temperature $\left({ }^{\circ} \mathrm{C}\right)$ & Pretreatment Time $(\mathrm{h})$ & H-factor \\
\hline 150 & 2 & 329 \\
\hline 170 & 1 & 920 \\
\hline 170 & 2 & 1840 \\
\hline 170 & 3 & 2760 \\
\hline 190 & 2 & 8852 \\
\hline
\end{tabular}

\section{Enzymatic saccharification}

In this work, enzymatic saccharification was used to evaluate the effectiveness of pretreatment, according to the NREL standard procedure (Selig et al. 2008). The saccharification of pretreated wheat straw was conducted in a $50-\mathrm{mL}$ bottle with a substrate solid loading of $2 \mathrm{wt} \%$ in an incubator shaker $\left(50{ }^{\circ} \mathrm{C}, \mathrm{pH} 4.8\right.$, for $\left.48 \mathrm{~h}\right)$. Approximately $0.02 \mathrm{wt} \%$ sodium azide was added to prevent microbial contamination, and the cellulase dosage was $25 \mathrm{FPU} / \mathrm{g}$-glucan (23 mg protein/g-glucan). A high loading of enzyme was 
used due to the relatively low activity of cellulase. After saccharification, the samples of hydrolysate were taken out and immediately cooled to $4{ }^{\circ} \mathrm{C}$ for monosaccharide analysis with high performance liquid chromatography (HPLC).

\section{Preparation of submicron lignin spheres (SLS)}

The SLS particles were prepared via the self-assembly method using the acetylated lignin, as reported previously (Qian et al. 2014). Firstly, the purified lignin was acetylated in the mixed solution of acetic acid and acetyl bromide (volume ratio of acetic acid to acetyl bromide was $95: 5$ ) at $55^{\circ} \mathrm{C}$ for $3 \mathrm{~h}$, and the reaction was carried out in a single port flask $(500 \mathrm{~mL})$ in water bath with magnetic stirring $(200 \mathrm{rpm})$. Upon completion, the solvent was recovered by rotary evaporation under vacuum at $55{ }^{\circ} \mathrm{C}$, and then the solids were completely dried at $105^{\circ} \mathrm{C}$ for $2 \mathrm{~h}$ in a drier (DGH-9076A, Shanghai, China). After that, the resulting acetylated lignin was immediately dissolved in tetrahydrofuran (THF). Finally, the SLS particles were obtained through self-assembly when the deionized water was slowly and gradually added to the acetylated lignin-THF solution. In the resultant dispersion of SLS, the end volume ratio of water to THF was $67: 33$.

\section{Chemical composition analysis}

The chemical compositions of raw and pretreated wheat straw were tested based on the two-step sulfuric acid hydrolysis following the NREL procedure (Sluiter et al. 2008). After being filtered with $0.22-\mu \mathrm{m}$ membrane, the acidic and enzymatic hydrolyzates were analyzed by a HPLC system (Model 1200; Agilent, Santa Clara, CA, USA). A Bio-Rad Aminex HPX-87H column $(300 \mathrm{~mm} \times 7.8 \mathrm{~mm})$ and refractive index detector were equipped in the HPLC system, and the column was operated at $55^{\circ} \mathrm{C}$ with the mobile phase of $0.005 \mathrm{M}$ sulfuric acid solution at a flow rate of $0.6 \mathrm{~mL} / \mathrm{min}$. All samples were measured at least three times based on the calibration curve established with the standard sugars with the known and gradient concentrations. The sugar losses during acid hydrolysis were corrected by subjecting known amounts of standard sugars throughout the same test procedures. Equations 2 through 8 are as follows,

$$
\begin{aligned}
& R_{\text {solid }}(\%)=\frac{M_{\text {pretreated biomiss }}}{M_{\text {orignal biomiss }}} \times 100 \\
& R_{\text {glucan }}(\%)=\frac{M_{\text {glucan in pretreated biomiss }} \times R_{\text {solid }}}{M_{\text {glucan in orignal biomiss }}} \times 100 \\
& R_{\text {xylan }}(\%)=\frac{M_{\text {xylan in pretreated biomiss }} \times R_{\text {solid }}}{M_{\text {xylan in orignal biomiss }}} \times 100 \\
& D_{\text {lignin }}(\%)=\left(1-\frac{M_{\text {lignin in pretreated biomiss }} \times R_{\text {solid }}}{M_{\text {lignin in orignal biomiss }}}\right) \times 100 \\
& C_{\text {glucose }}(\%)=\frac{M_{\text {glucose in hydrolyzate }} \times 0.9}{M_{\text {glucan in pretreated biomiss }}} \times 100 \\
& C_{\text {xylose }}(\%)=\frac{M_{\text {xylose in hydrolyzate }} \times 0.88}{M_{\text {xylan in pretreated biomiss }}} \times 100 \\
& Y_{\text {total sugar }}(\%)=\frac{M_{\text {glucose in hydrolyzate }} \times 0.9+M_{\text {xylose in hydrolyzate }} \times 0.88}{M_{\text {glucan in orignal biomiss }}+M_{\text {xylan in orignal biomiss }}} \times 100
\end{aligned}
$$

where, $M$ is the mass of the corresponding substance $(\mathrm{g})$. 
The calculations for solid recovery $\left(R_{\text {solid }}\right)$, the recovery efficiencies of glucan $\left(R_{\text {glucan }}\right) / x y l a n\left(R_{\text {xylan }}\right)$, and the delignification efficiency $\left(D_{\text {lignin }}\right)$ after pretreatment, as well as the enzymatic conversion extents of glucan $\left(C_{\text {glucan }}\right) / x y l a n\left(C_{\text {xylan }}\right)$ and the final total sugar yields (glucose + xylose) $\left(Y_{\text {total sugar }}\right)$ after saccharification were carried out following the previous work (Xie et al. 2018), and the detailed calculation equations are given in Eqs. 2 to 8 . In brief, $R_{\text {glucan }}$ and $R_{\text {xylan }}$ indicate how much glucan and xylan remained in the pretreated wheat straw, respectively. The $C_{\text {glucan }}$ and $C_{\text {xylan }}$ are defined as the percentages of the released glucose and xylose in enzymatic hydrolyzate after saccharification divided by the corresponding glucan and xylan in the pretreated wheat straw accordingly. The $Y_{\text {total }}$ sugar is defined as the percent of the released glucose plus xylose in hydrolysate after saccharification divided by the corresponding total sugars in original wheat straw.

In this work, all experiments of pretreatment, enzymatic saccharification, and chemical composition were conducted at least three times, and the average value with standard deviation are reported accordingly. The statistical analyses were performed using Microsoft Excel 2013.

\section{Characterizations}

The surface morphologies of wheat straw and SLS were observed with a scanning electron microscope (SEM, S-4800; Hitachi, Tokyo, Japan) with the accelerating voltages from 3.0 to $8.0 \mathrm{kV}$, and the freeze-dried samples were coated with platinum (E-1045; Hitachi, Tokyo, Japan) before observation.

Fourier transform infrared spectroscopy (FTIR) spectra of wheat straw before and after pretreatment were recorded on a spectrometer (Nicolet 6700; Thermo Fisher, Waltham, MA, USA) in the wavenumber range of 4000 to $500 \mathrm{~cm}^{-1}$ at resolution $4 \mathrm{~cm}^{-1}$. Samples were prepared using the standard $\mathrm{KBr}$ pellet method, and 32 scans were collected for each sample. The absorption peaks at 2900, 1430, 1372, and $897 \mathrm{~cm}^{-1}$ were used for the calculation of cellulose crystalline index. The total crystallinity index (TCI) of cellulose was computed as the ratio of absorption peak at 1372 to $2900 \mathrm{~cm}^{-1}$ (Nelson and O'Connor 1964), and the lateral order index ( $L O I)$ of cellulose was calculated as the ratio of absorption peak at 1430 to $897 \mathrm{~cm}^{-1}$ (Hurtubise and Krassig 1960).

The crystallinity index $(\mathrm{CrI})$ of the raw and pretreated wheat straw was determined using an X-ray diffraction (XRD) instrument (D8 ADVANCE; Bruker Co., Karlsruhe, Germany) with the Ni-filtered $\mathrm{Cu} \mathrm{K \alpha}$ radiation of $80 \mathrm{~mA}$ and $40 \mathrm{kV}$. The scanning speed was $0.5^{\circ} / \mathrm{min}$ in the scattering angle $(2 \theta)$ range of 5 to $45^{\circ}$, and the $C r I$ was calculated in terms of the empirical method reported by Segal et al. (1959).

The specific surface area and pore volume of raw and pretreated wheat straw samples were measured with a Brunauer-Emmet-Teller (BET) surface integral analyzer (Autosorb-iQ; Quantachrome, Boynton, FL, USA) at $\mathrm{N}_{2}$ environment with the test models of BET theory and Barrett-Joyner-Halenda (BJH) method, respectively. Before testing, samples were lyophilized for $24 \mathrm{~h}$ and degassed under vacuum at $80{ }^{\circ} \mathrm{C}$ for $8 \mathrm{~h}$.

The organic elements of $\mathrm{C}, \mathrm{H}, \mathrm{O}, \mathrm{N}$, and $\mathrm{S}$ in the raw and pretreated wheat straw were analyzed on an elemental analyzer (Vario EL cube; Elementar Co., Hanau, Germany) after the samples were burned with oxygen at temperature of $1200{ }^{\circ} \mathrm{C}$ for $70 \mathrm{~s}$.

The molecular weight of acetylated lignin was tested by gel permeation chromatography (GPC, HELEOS System; Wyatt Co., Santa Barbara, CA, USA) with a refractive index detector (G1362A). The mobile phase was THF and the flow rate was 1 $\mathrm{mL} / \mathrm{min}$. Polystyrene was used as the standard material for calibration. 
The morphologies of the as-prepared SLS were characterized using a transmission electron microscope (TEM, Hitachi H-7600; Hitachi, Tokyo, Japan) with an accelerating voltage of $120 \mathrm{kV}$ and atomic force microscope (AFM, Agilent 5400, Palo Alto, CA, USA) in the tapping mode, respectively.

\section{RESULTS AND DISCUSSION}

It is well known that biomass pretreatment is essential for the facilitation of sugar release in enzymatic saccharification (Li et al. 2017; Xie et al. 2018). On the basis of structure features of lignocelluloses and the requirements of industrial application, a good pretreatment method should meet the requirements of high recovery of polysaccharides, limited formation of inhibitors, suitable fractionation and utilization of lignin, low chemical consumption or efficient chemical recovery, low energy consumption and reduced wastewater, and most importantly, high compatibility with enzymatic saccharification (Mosier et al. 2005; Liu et al. 2020).

\section{Impact of Key Process Variables on the Effectiveness of AEW Pretreatment}

In this work, AEW pretreatment was applied to treat wheat straw. The impact of key variables of ethanol concentration, ammonia dosage, and energy input on the effectiveness of AEW pretreatment was evaluated in terms of $R_{\text {solid }}, R_{\text {glucan }}, R_{\text {xylan }}, D_{\text {lignin }}$, and the standard enzymatic hydrolysis.

In ethanol organosolv pretreatment, ethanol concentration is of vital importance for pretreatment efficiency. Shown in Fig. 1a and 1b are the impact of ethanol concentration on the effect of AEW pretreatment of wheat straw. The ethanol concentration ranged from 0 to $78 \%(\mathrm{v} / \mathrm{v})$ with the fixed ammonia dosage of $5 \mathrm{wt} \%$ at $170{ }^{\circ} \mathrm{C}$ for $2 \mathrm{~h}$. As shown in Fig. 1a, after AEW pretreatment, both $R_{\text {glucan }}$ and $R_{\text {xylan }}$ increased with the increase of ethanol concentration. For instance, the $R_{\text {glucan }}$ and $R_{\text {xylan }}$ increased $15.3 \%$ and $58.9 \%$, respectively, when ethanol concentration increased from 0 to $55 \%(\mathrm{v} / \mathrm{v})$. These results indicated that higher ethanol concentration could reduce the degradation of carbohydrates (particularly for xylan) in AEW pretreatment, which was probably because both cellulose and xylan are insoluble in ethanol. Figure 1a also exhibits that the lignin removal ascended approximately $50 \%$ when ethanol concentration increased from 0 to $37 \%$ (v/v), which was because ethanol could promote the impregnation of plant tissue by transferring reagents to lignin, and simultaneously transport the soluble lignin fragments from the inside tissue to the bulk solution (Zhou et al. 2018). However, the $D_{\text {lignin }}$ descended when ethanol concentration was higher than $55 \%(\mathrm{v} / \mathrm{v})$. This phenomenon was because higher concentration of ethanol could reduce the reaction between $\mathrm{NH}_{3}$ and $\mathrm{H}_{2} \mathrm{O}$, generating less $\mathrm{OH}^{-}$, which was in line with the decreased $\mathrm{pH}$ in a higher ethanol concentration (Fig. 1a). A weaker alkalinity reduced the lignin degradation. Moreover, the AEW fractionated lignin via ammonolysis might have a lower solubility in a higher ethanol concentration, because different lignin has distinct hydrogen-bonding capacity in different solvents ( $\mathrm{Ni}$ and $\mathrm{Hu}$ 1995). Thus, the increase of the preservation of carbohydrates and the decrease of $D_{\text {lignin }}$ led to a rise of $R_{\text {solid }}$ when the ethanol concentration was over $55 \%(\mathrm{v} / \mathrm{v})$. Correspondingly, as displayed in Fig. $1 \mathrm{~b}$, the $C_{\text {glucan }}, C_{\text {xylan }}$, and $Y_{\text {total sugar }}$ had similar trends with $D_{\text {lignin. }}$ This phenomenon was because lignin content in pretreated substrate is one of main hindrances to enzymatic hydrolysis (Xie et al. 2018). In fact, based on all data obtained in this work, it was found that lignin content had a linearly negative impact on enzymatic conversion 
and $Y_{\text {total sugar }}$ (Fig. 2). Similar correlations were also reported previously for alkali-based pretreatments (Yang et al. 2013; Xu et al. 2015). With the ethanol concentration of 55\% $(\mathrm{v} / \mathrm{v})$ and ammonia dosage of $5 \mathrm{wt} \%, D_{\text {lignin }}$ after AEW pretreatment could only reach $61 \%$ (Fig. 1a) and the corresponding $Y_{\text {total sugar }}$ after saccharification was only approximately $64 \%$ (Fig. 1b). Hence, to further boost lignin removal and $Y_{\text {total sugar, ammonia dosage can }}$ be properly increased.


Fig. 1. Effect of ethanol concentration and ammonia dosage on the effectiveness of $A E W$ pretreatment (a: impact of ethanol concentration on recovery and delignification, ammonia dosage $5 \mathrm{wt} \%, 170^{\circ} \mathrm{C}$ for $2 \mathrm{~h}$; b: impact of ethanol concentration on enzymatic conversion and final total sugar yield, ammonia dosage $5 \mathrm{wt} \%, 170{ }^{\circ} \mathrm{C}$ for $2 \mathrm{~h}$; c: impact of ammonia dosage on recovery and delignification, ethanol concentration $55 \%(\mathrm{v} / \mathrm{v}), 170^{\circ} \mathrm{C}$ for $2 \mathrm{~h}$; d: impact of ammonia dosage on enzymatic conversion and final total sugar yield, ethanol concentration $55 \%$ $(\mathrm{v} / \mathrm{v}), 170^{\circ} \mathrm{C}$ for $\left.2 \mathrm{~h}\right)$

Figures 1c and 1d present the impact of ammonia dosage on the effect of AEW pretreatment with the fixed ethanol concentration of $55 \%(\mathrm{v} / \mathrm{v})$ at $170{ }^{\circ} \mathrm{C}$ for $2 \mathrm{~h}$. It can be observed from Fig. 1c that the $\mathrm{pH}$ value kept increasing with the increment of ammonia dosage. This is because $\mathrm{NH}_{3}$ can react with $\mathrm{H}_{2} \mathrm{O}$, releasing the nucleophilic reagent $\mathrm{OH}^{-}$ ions, which have a higher activity to attack lignin. As known, aqueous ammonia can swell lignocelluloses and enhance lignin removal by breaking aryl-ether bonds in lignin (mainly the dearylation of non-phenolic $\beta$-aryl ether bonds) as well as ester and ether bonds in the lignin-carbohydrate complex under the attack of $\mathrm{OH}^{-}$and $\mathrm{NH}_{3}$ (Kim et al. 2003; Hashemi et al. 2019). Thus, with the increase of ammonia dosage from 0 to $60 \mathrm{wt} \%, D_{\text {lignin }}$ kept increasing from 51.4 to $76.9 \%$, and that was an approximate $50 \%$ increase of lignin removal. Additionally, to achieve a higher ammonia dosage over $60 \mathrm{wt} \%$, the raw wheat 
straw was completely dried for tuning of the ratio of ethanol to aqueous ammonia without adding of additional water before pretreatment. However, as shown in Fig. 1c, when ammonia dosage increased to 80 to $100 \mathrm{wt} \%$, the corresponding $D_{\text {lignin }}(67$ to $70 \%$ ) was clearly lower compared to the one (approximate 77\%) with the ammonia dosage of $60 \mathrm{wt} \%$. This result was due to the more compact structure of wheat straw induced by water loss after complete drying (Luo et al. 2011), which could reduce mass transfer in pretreatment. Therefore, the corresponding enzymatic conversion and $Y_{\text {total sugar }}$ were all decreased greatly (Fig. 1d) because of the less removal of lignin (thus less accessibility of substrate to cellulase) along with some degradation (approximately 3\% more) of carbohydrates. In addition, Fig. 1c also displays that the increase of ammonia dosage from 5 to $100 \mathrm{wt} \%$ did not cause severe degradation of carbohydrates, and the $R_{\text {glucan }}$ and $R_{\text {xylan }}$ varied in the ranges of 89 to $93 \%$ and 75 to $81 \%$, respectively. Again, lignin content of pretreated wheat straw (i.e., lignin removal) was closely related to the enzymatic conversion and $Y_{\text {total sugar }}$ (Figs. 1 and 2), and the highest $Y_{\text {total sugar }}$ of $81.4 \%$ could be achieved with the $D_{\text {lignin }}$ of $77 \%$. To achieve this point, the suitable ammonia dosage was $60 \mathrm{wt} \%$ for AEW pretreatment.

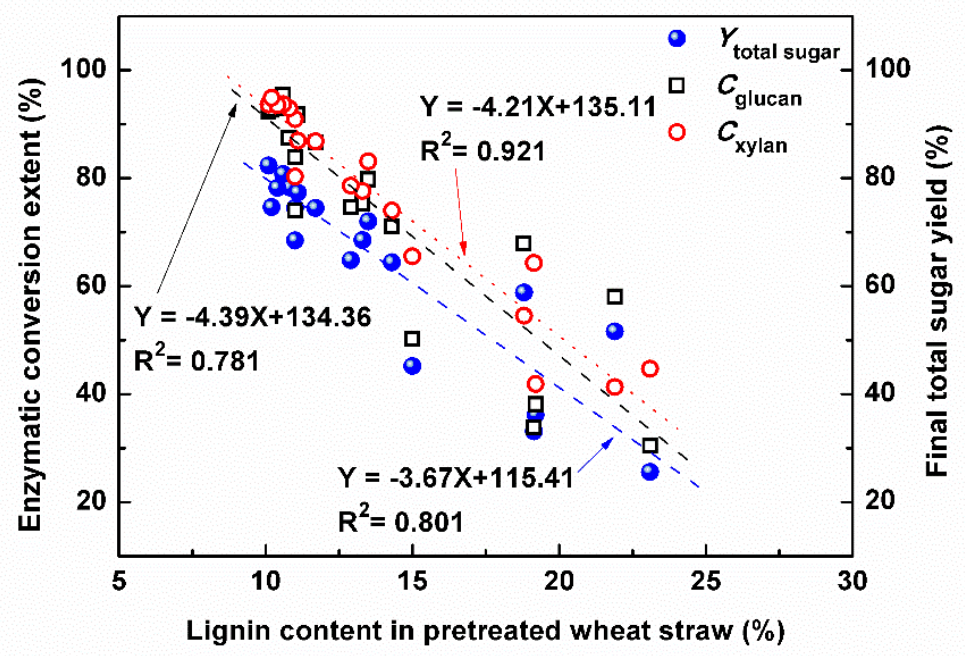

Fig. 2. Correlations between the lignin content of pretreated wheat straw and enzymatic conversion / final total sugar yields

Energy input (presented as $\mathrm{H}$-factor) in pretreatment also plays an important role on pretreatment efficiency and process cost. The impact of $\mathrm{H}$-factor on the effectiveness of AEW pretreatment is shown in Fig. 3. In the range of $\mathrm{H}$-factor from 329 to 8852 , the ethanol concentration and ammonia dosage were fixed at $55 \%(\mathrm{v} / \mathrm{v})$ and $60 \mathrm{wt} \%$, respectively. As expected, $R_{\text {solid }}$ decreased with the increase of $\mathrm{H}$-factor, because more energy input could promote chemical reactions in pretreatment (Sixta 2006), leading to more lignin removal and more degradation of carbohydrates (Fig. 3a). Additionally, when $\mathrm{H}$-factor ascended from $329\left(150{ }^{\circ} \mathrm{C}, 2 \mathrm{~h}\right)$ to $1840\left(170{ }^{\circ} \mathrm{C}, 2 \mathrm{~h}\right)$, the increased lignin removal was closely related to the increase of $C_{\text {glucan }}, C_{\text {xylan }}$, and $Y_{\text {total sugar. }}$ For example, when $\mathrm{H}$-factor increased from 920 to $1840, D_{\text {lignin }}$ increased approximately $5 \%$, and the

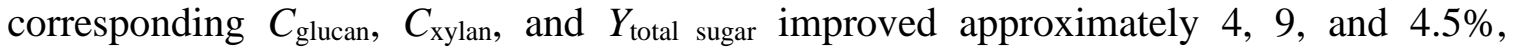
respectively. However, when $\mathrm{H}$-factor was higher than 1840 , severe degradation of glucan and xylan took place, resulting in the decrease of $Y_{\text {total sugar, although both the corresponding }}$ $C_{\text {glucan }}$ and $C_{\text {xylan }}$ were basically steady over $90 \%$ (Fig. $3 \mathrm{~b}$ ). Therefore, to obtain a higher 
$Y_{\text {total sugar, }}$ excessive increase of $\mathrm{H}$-factor is not needed, because severe degradation of carbohydrates should be avoided.
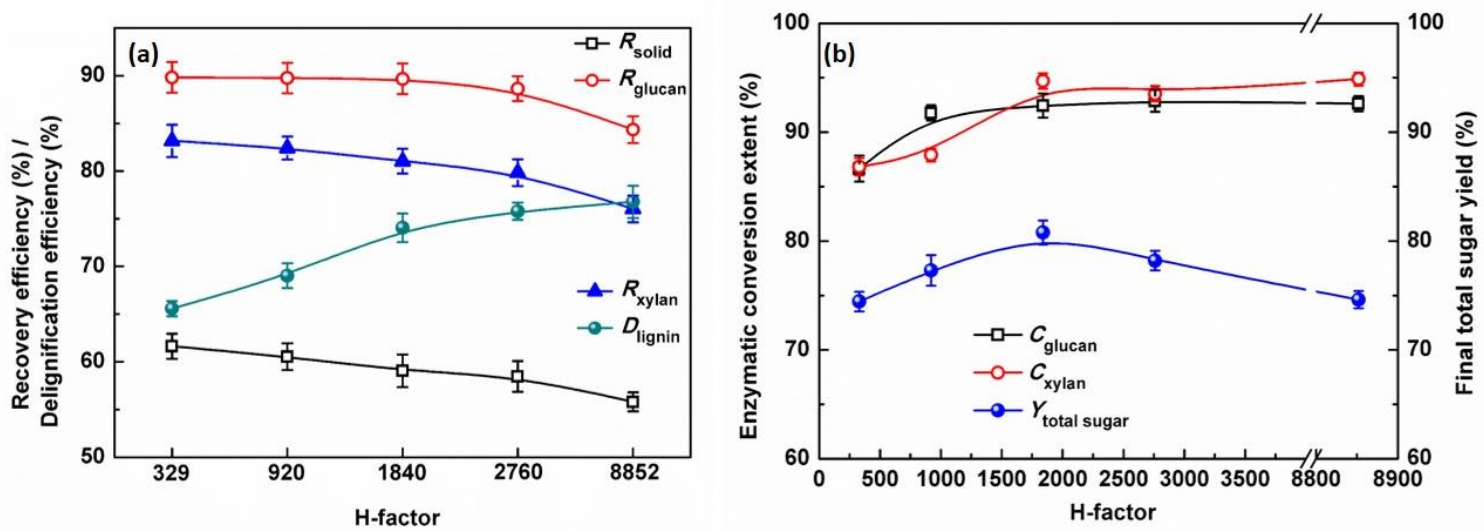

Fig. 3. Effect of $\mathrm{H}$-factor on the effectiveness of AEW pretreatment (a: for recovery and delignification; $b$ : for enzymatic conversion and final total sugar yield)

Based on the results obtained, the suitable $\mathrm{H}$-factor was 1840 , corresponding to the energy input at $170{ }^{\circ} \mathrm{C}$ for $2 \mathrm{~h}$, and the suitable ethanol concentration and ammonia dosage were $55 \%(\mathrm{v} / \mathrm{v})$ and $60 \mathrm{wt} \%$, respectively. Under such conditions, the corresponding $C_{\text {glucan, }}$ $C_{\text {xylan, and }} Y_{\text {total sugar }}$ could reach up to $92.4 \pm 1.1,94.1 \pm 0.7$, and $81.7 \pm 1.0 \%$, respectively. This $Y_{\text {total sugar }}$ was 2.25 times higher compared to the ethanol organosolv pretreatment without any addition of ammonia (only $36.8 \pm 1.2 \%$, Fig. 1d).

Furthermore, the $C_{\text {glucan }}, C_{\text {xylan }}$, and $Y_{\text {total sugar }}$ as the function of enzymatic hydrolysis time for the wheat straw pretreated under the optimal conditions are exhibited in Fig. 4.

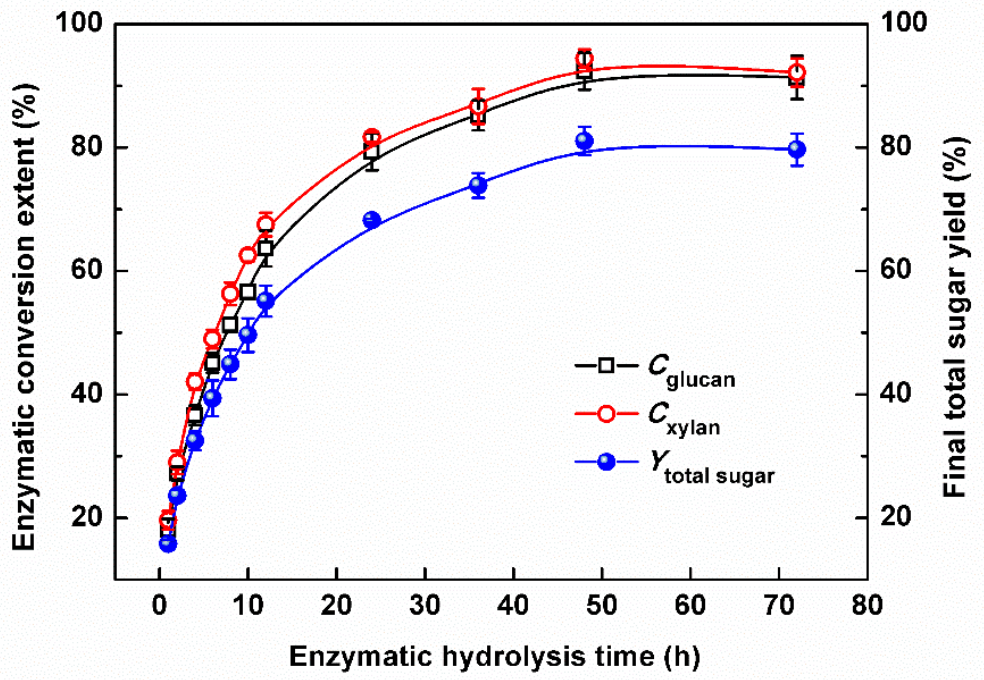

Fig. 4 Enzymatic conversion extent and final total sugar yield as the function of enzymatic hydrolysis time (wheat straw pretreated at $170{ }^{\circ} \mathrm{C}$ for $2 \mathrm{~h}$ with ethanol concentration of $55 \%(\mathrm{v} / \mathrm{v})$ and ammonia dosage of $60 \mathrm{wt} \%$ )

As shown, the $C_{\text {glucan }}, C_{\text {xylan}}$, and $Y_{\text {total sugar }}$ increased rapidly in the first $24 \mathrm{~h}$ (especially in the first $12 \mathrm{~h}$ ), indicating a high accessibility of the pretreated wheat straw after sufficient removal of lignin and extractives. As shown in Tables 2 through 4, the 
remaining extractives of the AEW-pretreated wheat straw were in the range of 2.1 to 5.6\%, which was obviously lower than the extractives content $(14.4 \%)$ of raw wheat straw and the alkali pretreated wheat straw (7.4 to 12.4\%) (Xie et al. 2018). The highest removal efficiency of extractives could reach $90 \%$ after AEW pretreatment, which was probably because wheat straw contains over $50 \%$ of lipophilic extractives and these lipophilic extractives (such as fatty acids, waxes, steryl esters) could be easily extracted by ethanol (Sun and Suan 2001). However, AEW pretreatment could not efficiently remove ash (Tables 2 through 4). Both extractives and ash had a barrier effect on saccharification as well (Yuan et al. 2018).

Table 2. Effect of Ethanol Concentration on the Chemical Composition of AEWpretreated Wheat Straw

\begin{tabular}{|c|c|c|c|c|c|c|}
\hline $\begin{array}{c}\text { Ethanol } \\
\text { Concentration } \\
(\%)\end{array}$ & $R_{\text {solid }}(\%)$ & Glucan (\%) & Xylan (\%) & Lignin (\%) & $\begin{array}{c}\text { Extractives } \\
(\%)\end{array}$ & Ash (\%) \\
\hline 0 & $55.8 \pm 0.1$ & $41.7 \pm 0.1$ & $13.5 \pm 0.1$ & $23.1 \pm 0.1$ & $4.9 \pm 0.4$ & $9.3 \pm 0.5$ \\
\hline 18 & $56.0 \pm 0.1$ & $45.9 \pm 0.3$ & $15.5 \pm 0.3$ & $19.1 \pm 0.4$ & $4.8 \pm 0.2$ & $10.7 \pm 0.9$ \\
\hline 37 & $56.0 \pm 0.2$ & $47.0 \pm 0.3$ & $17.1 \pm 0.2$ & $15.0 \pm 0.5$ & $4.3 \pm 0.5$ & $11.8 \pm 0.1$ \\
\hline 55 & $59.3 \pm 0.1$ & $45.2 \pm 0.4$ & $20.2 \pm 0.2$ & $14.3 \pm 0.4$ & $4.2 \pm 0.3$ & $9.6 \pm 0.4$ \\
\hline 67 & $62.8 \pm 0.4$ & $44.1 \pm 0.4$ & $19.8 \pm 0.1$ & $18.8 \pm 0.5$ & $3.3 \pm 0.2$ & $10.2 \pm 0.3$ \\
\hline 78 & $69.4 \pm 0.3$ & $42.0 \pm 0.2$ & $18.7 \pm 0.2$ & $21.9 \pm 0.4$ & $4.5 \pm 0.4$ & $9.7 \pm 1.2$ \\
\hline
\end{tabular}

Composition of raw wheat straw: glucan $30.3 \pm 0.2 \%$, xylan $13.5 \pm 0.1 \%$, lignin $25.1 \pm 0.3 \%$, extractives $14.4 \pm 0.7 \%$, and ash $13.6 \pm 0.1 \%$

Table 3. Effect of Ammonia Dosage on the Chemical Composition of AEWpretreated Wheat Straw

\begin{tabular}{|c|c|c|c|c|c|c|}
\hline $\begin{array}{c}\text { Ammonia } \\
\text { Dosage (\%) }\end{array}$ & $R_{\text {solid }}(\%)$ & Glucan (\%) & Xylan (\%) & Lignin (\%) & $\begin{array}{c}\text { Extractives } \\
(\%)\end{array}$ & Ash (\%) \\
\hline 0 & $63.6 \pm 0.4$ & $46.4 \pm 0.5$ & $17.2 \pm 0.4$ & $19.2 \pm 0.4$ & $5.6 \pm 0.3$ & $12.0 \pm 0.1$ \\
\hline 5 & $59.3 \pm 0.1$ & $45.2 \pm 0.4$ & $20.2 \pm 0.2$ & $14.3 \pm 0.4$ & $4.2 \pm 0.2$ & $10.7 \pm 0.4$ \\
\hline 10 & $59.0 \pm 0.3$ & $50.0 \pm 0.1$ & $19.1 \pm 0.0$ & $11.0 \pm 0.2$ & $3.7 \pm 0.4$ & $9.6 \pm 0.1$ \\
\hline 20 & $58.8 \pm 0.7$ & $47.0 \pm 0.6$ & $17.7 \pm 0.5$ & $11.0 \pm 0.6$ & $3.2 \pm 0.2$ & $10.1 \pm 0.5$ \\
\hline 40 & $57.5 \pm 0.4$ & $49.0 \pm 0.6$ & $18.1 \pm 0.3$ & $10.8 \pm 0.2$ & $2.9 \pm 0.5$ & $9.2 \pm 0.3$ \\
\hline 60 & $57.2 \pm 0.3$ & $49.5 \pm 0.3$ & $18.5 \pm 0.1$ & $10.1 \pm 0.3$ & $2.1 \pm 0.3$ & $10.7 \pm 0.7$ \\
\hline 80 & $61.3 \pm 0.3$ & $45.9 \pm 0.2$ & $17.8 \pm 0.2$ & $13.5 \pm 0.3$ & $5.1 \pm 0.4$ & $10.9 \pm 0.2$ \\
\hline 90 & $59.2 \pm 0.2$ & $48.1 \pm 0.5$ & $18.6 \pm 0.4$ & $13.3 \pm 0.2$ & $3.7 \pm 0.2$ & $9.5 \pm 1.3$ \\
\hline 100 & $58.2 \pm 0.4$ & $46.4 \pm 0.4$ & $18.0 \pm 0.2$ & $12.9 \pm 0.4$ & $5.0 \pm 0.4$ & $9.8 \pm 1.6$ \\
\hline
\end{tabular}

Composition of raw wheat straw: glucan $30.3 \pm 0.2 \%$, xylan $13.5 \pm 0.1 \%$, lignin $25.1 \pm 0.3 \%$, extractives $14.4 \pm 0.7 \%$, and ash $13.6 \pm 0.1 \%$

Figure 4 also shows that after $24 \mathrm{~h}$ hydrolysis, the increase of conversion $\left(C_{\text {glucan }}\right.$ and $\left.C_{\text {xylan }}\right)$ and final sugar yield gradually became slow, which was due to the inhibition effect of the increased sugar concentration (Jing et al. 2009). After 48 h hydrolysis, the 
$C_{\text {glucan }}, C_{\text {xylan, }}$ and $Y_{\text {total sugar }}$ basically kept steady, indicating the end of enzymatic saccharification. Interestingly, $C_{\text {xylan }}$ was higher than $C_{\text {glucan }}$ (Fig. 4), which was probably because most extracted xylan was likely re-adsorbed on the surface of AEW-pretreated wheat straw as xylan was not soluble in ethanol, leading to a higher exposure of xylan to enzymes (the enzyme used in this work contained some xylanase), and thus a higher $C_{\text {xylan }}$ could be obtained.

Table 4. Effect of $\mathrm{H}$-factor on the Chemical Composition of AEW-pretreated Wheat Straw

\begin{tabular}{|c|c|c|c|c|c|c|c|}
\hline $\begin{array}{c}\text { Energy } \\
\text { Input }\end{array}$ & H-factor & $\begin{array}{c}R_{\text {solid }} \\
(\%)\end{array}$ & Glucan (\%) & $\begin{array}{c}\text { Xylan } \\
(\%)\end{array}$ & $\begin{array}{c}\text { Lignin } \\
(\%)\end{array}$ & $\begin{array}{c}\text { Extractives } \\
(\%)\end{array}$ & $\begin{array}{c}\text { Ash } \\
(\%)\end{array}$ \\
\hline $150^{\circ} \mathrm{C} 2 \mathrm{~h}$ & 329 & $61.6 \pm 0.5$ & $47.2 \pm 0.5$ & $20.1 \pm 0.3$ & $11.7 \pm 0.6$ & $5.4 \pm 0.2$ & $11.6 \pm 0.3$ \\
\hline $170^{\circ} \mathrm{C} 1 \mathrm{~h}$ & 920 & $60.5 \pm 0.4$ & $48.1 \pm 0.4$ & $20.2 \pm 0.3$ & $11.1 \pm 0.5$ & $4.4 \pm 0.4$ & $10.9 \pm 0.1$ \\
\hline $170^{\circ} \mathrm{C} 2 \mathrm{~h}$ & 1840 & $59.1 \pm 0.7$ & $50.2 \pm 0.8$ & $20.3 \pm 0.7$ & $10.6 \pm 1.1$ & $2.6 \pm 0.7$ & $9.8 \pm 1.2$ \\
\hline $170^{\circ} \mathrm{C} 3 \mathrm{~h}$ & 2760 & $58.5 \pm 0.2$ & $49.1 \pm 0.3$ & $20.2 \pm 0.4$ & $10.4 \pm 0.3$ & $3.4 \pm 1.3$ & $10.1 \pm 0.7$ \\
\hline $190^{\circ} \mathrm{C} 2 \mathrm{~h}$ & 8852 & $55.8 \pm 0.4$ & $49.0 \pm 0.3$ & $20.2 \pm 0.3$ & $10.2 \pm 0.4$ & $3.7 \pm 0.5$ & $9.7 \pm 1.4$ \\
\hline
\end{tabular}

Composition of raw wheat straw: glucan $32.4 \pm 0.2 \%$, xylan $14.8 \pm 0.3 \%$, lignin $21.6 \pm 0.4 \%$, extractives $14.5 \pm 0.9 \%$, and ash $14.5 \pm 0.4 \%$

In addition, the effect of washing after AEW pretreatment on enzymatic conversion and final sugar yields is demonstrated in Table 5, which depicts that sufficient washing could wash out the extracted lignin, extractives, and degraded carbohydrates, leading to a lower $R_{\text {solid. }}$. More removal of lignin and extractives yielded higher $C_{\text {glucan }}$ and $C_{\text {xylan }}$, but comparable $Y_{\text {total sugar }}$ could be obtained after AEW pretreatment with or without washing. Based on variance analysis, for the samples with ammonia dosage of 40 or $60 \mathrm{wt} \%$ (Table $5)$, the effect of washing after pretreatment on $Y_{\text {total sugar }}$ was statistically different $(0.01<$ P-value $<0.05$ ), but the difference of $Y_{\text {total sugar }}$ (with or without washing) was still comparable $(<1.5 \%)$. For the samples with ammonia dosage of 80 or $90 \mathrm{wt} \%$ (Table 5),

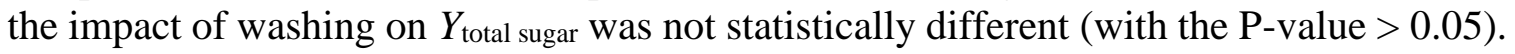
The comparable $Y_{\text {total sugar }}$ with or without washing was because parts of degraded carbohydrates remained in the pretreated wheat straw after phase separation but without washing, hence offsetting the sugar loss of carbohydrates degradation in pretreatment with washing. Please note that, under the alkaline conditions, 5-hydroxymethylfurfural (5$\mathrm{HMF}$ ) and furfural were not detectable in the spent liquor of AEW pretreatment, and this was also beneficial to the followed enzymatic hydrolysis of the pretreated wheat straw without washing. Therefore, the washing step could be omitted after AEW pretreatment before saccharification, which will reduce the cost for the production of fermentable sugars. 
Table 5. Effect of Washing on the Effectiveness of AEW Pretreatment

\begin{tabular}{|c|c|c|c|c|c|c|c|c|c|}
\hline $\begin{array}{c}\mathrm{NH}_{3} \\
\text { Dosage } \\
\text { (wt\%) }\end{array}$ & $\begin{array}{l}\text { Washing } \\
\text { (Yes/No) }\end{array}$ & $\begin{array}{l}R_{\text {solid }} \\
(\%)\end{array}$ & $\begin{array}{c}R_{\text {glucan }} \\
(\%)\end{array}$ & $\begin{array}{c}R_{\text {xylan }} \\
(\%)\end{array}$ & $\begin{array}{c}D_{\text {lignin }} \\
(\%)\end{array}$ & $\begin{array}{c}\text { Extractives } \\
\text { Content } \\
(\%)\end{array}$ & $\begin{array}{c}C_{\text {glucan }} \\
(\%)\end{array}$ & $\begin{array}{c}C_{\text {xylan }} \\
(\%)\end{array}$ & $\begin{array}{l}Y_{\text {total }} \\
\text { sugar } \\
(\%)\end{array}$ \\
\hline \multirow{2}{*}{40} & Yes & $\begin{array}{c}57.5 \pm \\
0.4\end{array}$ & $\begin{array}{c}93.0 \pm \\
0.7\end{array}$ & $\begin{array}{c}77.1 \pm \\
0.4\end{array}$ & $\begin{array}{c}75.3 \pm \\
0.8\end{array}$ & $2.9 \pm 0.3$ & $\begin{array}{c}91.1 \pm \\
0.2\end{array}$ & $\begin{array}{c}93.4 \pm \\
0.1\end{array}$ & $\begin{array}{c}75.1 \pm \\
0.3\end{array}$ \\
\hline & No & $\begin{array}{c}68.6 \pm \\
0.3\end{array}$ & $\begin{array}{c}93.8 \pm \\
0.1\end{array}$ & $\begin{array}{c}78.4 \pm \\
0.6\end{array}$ & $\begin{array}{c}68.6 \pm \\
1.1\end{array}$ & $16.9 \pm 0.7$ & $\begin{array}{c}86.9 \pm \\
0.5\end{array}$ & $\begin{array}{c}84.7 \pm \\
0.9\end{array}$ & $\begin{array}{c}73.8 \pm \\
0.6\end{array}$ \\
\hline \multirow{2}{*}{60} & Yes & $\begin{array}{c}57.2 \pm \\
0.7\end{array}$ & $\begin{array}{c}92.6 \pm \\
0.3 \\
\end{array}$ & $\begin{array}{c}78.4 \pm \\
0.2 \\
\end{array}$ & $\begin{array}{c}77.0 \pm \\
0.3\end{array}$ & $2.1 \pm 0.6$ & $\begin{array}{c}93.2 \pm \\
0.7\end{array}$ & $\begin{array}{c}94.9 \pm \\
0.3\end{array}$ & $\begin{array}{c}81.7 \pm \\
0.2\end{array}$ \\
\hline & No & $\begin{array}{c}67.8 \pm \\
1.0\end{array}$ & $\begin{array}{c}93.4 \pm \\
0.8\end{array}$ & $\begin{array}{c}86.5 \pm \\
1.3\end{array}$ & $\begin{array}{c}70.3 \pm \\
0.7\end{array}$ & .2 & $\begin{array}{c}91.8 \pm \\
0.1\end{array}$ & $\begin{array}{c}85.7 \pm \\
1.4\end{array}$ & $\begin{array}{c}80.2 \pm \\
0.6\end{array}$ \\
\hline \multirow{2}{*}{80} & Yes & $\begin{array}{c}61.3 \pm \\
0.2\end{array}$ & $\begin{array}{c}92.1 \pm \\
0.3\end{array}$ & $\begin{array}{c}80.7 \pm \\
0.9\end{array}$ & $\begin{array}{c}69.5 \pm \\
1.4\end{array}$ & 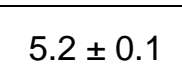 & $\begin{array}{c}79.1 \pm \\
0.3\end{array}$ & $\begin{array}{c}82.6 \pm \\
0.1\end{array}$ & $\begin{array}{c}71.9 \pm \\
0.4\end{array}$ \\
\hline & No & $\begin{array}{c}75.0 \pm \\
0.6\end{array}$ & $\begin{array}{c}92.9 \pm \\
0.4\end{array}$ & $\begin{array}{c}92.2 \pm \\
0.7\end{array}$ & $\begin{array}{c}59.7 \pm \\
0.2\end{array}$ & \pm 0.5 & $\begin{array}{c}77.4 \pm \\
0.5\end{array}$ & $\begin{array}{c}78.1 \pm \\
1.2\end{array}$ & $\begin{array}{c}70.3 \pm \\
0.9\end{array}$ \\
\hline \multirow{2}{*}{90} & Yes & $\begin{array}{c}59.2 \pm \\
0.1\end{array}$ & $\begin{array}{c}89.4 \pm \\
0.3\end{array}$ & $\begin{array}{c}78.9 \pm \\
0.1\end{array}$ & $\begin{array}{c}68.6 \pm \\
0.5\end{array}$ & \pm 0 & $\begin{array}{c}78.5 \pm \\
0.1\end{array}$ & $\begin{array}{c}81.1 \pm \\
0.6\end{array}$ & $\begin{array}{c}70.5 \pm \\
1.1\end{array}$ \\
\hline & No & $\begin{array}{c}72.0 \pm \\
0.3\end{array}$ & $\begin{array}{c}90.3 \pm \\
0.6\end{array}$ & $\begin{array}{c}89.5 \pm \\
0.9\end{array}$ & $\begin{array}{c}61.7 \pm \\
1.1\end{array}$ & $15.0 \pm 0.7$ & $\begin{array}{c}77.8 \pm \\
0.6\end{array}$ & $\begin{array}{c}79.7 \pm \\
0.8\end{array}$ & $\begin{array}{c}71.2 \pm \\
0.5\end{array}$ \\
\hline
\end{tabular}

\section{Feature Changes of Wheat Straw Before and After Pretreatment}

Feature changes of wheat straw before and after AEW pretreatment were comprehensively characterized, and further revealed why AEW pretreatment could clearly facilitate the enzymatic saccharification of wheat straw. Shown in Fig. 5 are the SEM images of wheat straw.

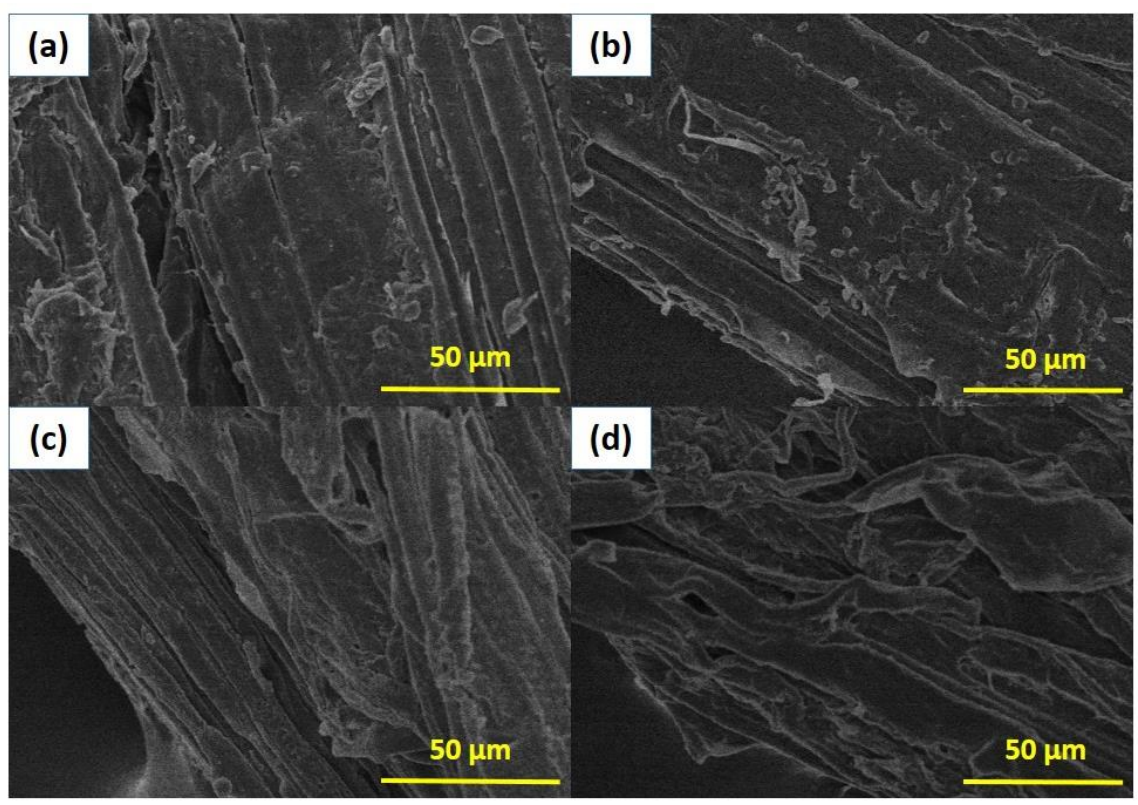

Fig. 5. SEM images of wheat straw before and after AEW pretreatment with a magnification of 800 times (a: raw materials; b: wheat straw pretreated at $150{ }^{\circ} \mathrm{C}$ for $2 \mathrm{~h}$ with ethanol concentration of $55 \%(\mathrm{v} / \mathrm{v})$ and ammonia dosage of $60 \mathrm{wt} \%$; c: wheat straw pretreated at $170{ }^{\circ} \mathrm{C}$ for $2 \mathrm{~h}$ with ethanol concentration of $18 \%(\mathrm{v} / \mathrm{v})$ and ammonia dosage of $60 \mathrm{wt} \%$; $\mathrm{d}$ : wheat straw pretreated at $170{ }^{\circ} \mathrm{C}$ for $2 \mathrm{~h}$ with ethanol concentration of $55 \%(\mathrm{v} / \mathrm{v})$ and ammonia dosage of 60 wt\%) 
As shown, raw wheat straw (smashed by extrusion) had a relatively smooth surface, and the fiber bundles were tightly compacted (Fig. 5a), indicating that pulverization by extrusion did not cause clear fiber delamination and fibrillation in this work. After AEW pretreatment, the fiber surface became rougher and the compact structure became looser under the relatively mild pretreatment conditions (Fig. 5b). With the increase of energy input, the fiber bundles were fragmented and the open structures could be clearly observed (Fig. 1c). Through further increasing ammonia dosage to $60 \mathrm{wt} \%$ in AEW pretreatment, the fiber bundles were remarkably loosened, a large number of long fibers were broken, and microfibers were clearly exposed (Fig. 5d), leading to the increments of specific surface area and porosity. In fact, based on BET analysis, the specific surface area and pore volume of wheat straw after AEW pretreatment under optimal conditions increased approximately $20 \%$ and $67 \%$, respectively, compared to the raw material. These phenomena were because AEW pretreatment could efficiently remove lignin and extractives (Fig. 1 and Tables 2 to 4), leading to the improvement of enzyme accessibility to pretreated substrates. Thus, the enzymatic conversion efficiencies of wheat straw were clearly promoted after AEW pretreatment (Figs. 1 and 3).

In addition, the removal of lignin and extractives after AEW pretreatment of wheat straw can also be verified by FTIR and XRD analyses. As displayed in Fig. 6, the relatively decreased intensities of the characteristic peaks of hemicelluloses (at $1740 \mathrm{~cm}^{-1}$ ) and lignin (at 1510 and $1423 \mathrm{~cm}^{-1}$ ), as well as the relatively increased intensity of the feature peak of cellulose (at $897 \mathrm{~cm}^{-1}$ ) indicated some degradation of hemicellulose (removal of acetyl groups and carboxylic acids) and delignification after pretreatment (Xie et al. 2018; Chen et al. 2019). Furthermore, crystallinity of lignocellulose is also an indicator of enzyme accessibility (Xu et al. 2019).

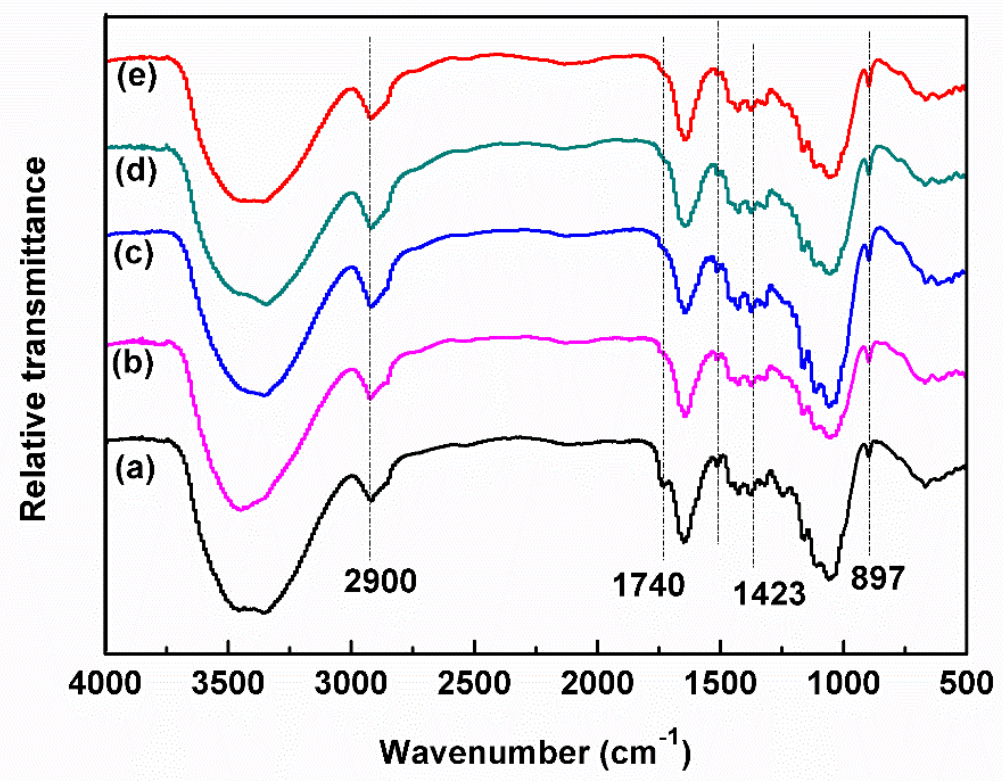

Fig. 6. FTIR spectra of wheat straw before and after AEW pretreatment (a: raw material; b: wheat straw pretreated at $150^{\circ} \mathrm{C}$ for $2 \mathrm{~h}$ with ethanol concentration of $55 \%(\mathrm{v} / \mathrm{v})$ and ammonia dosage of $60 \mathrm{wt} \%$; c: wheat straw pretreated at $170^{\circ} \mathrm{C}$ for $2 \mathrm{~h}$ with ethanol concentration of $18 \%(\mathrm{v} / \mathrm{v})$ and ammonia dosage of $60 \mathrm{wt} \%$; d: wheat straw pretreated at $170{ }^{\circ} \mathrm{C}$ for $2 \mathrm{~h}$ with ethanol concentration of $55 \%(\mathrm{v} / \mathrm{v})$ and ammonia dosage of $20 \mathrm{wt} \%$; e: wheat straw pretreated at $170{ }^{\circ} \mathrm{C}$ for $2 \mathrm{~h}$ with ethanol concentration of $55 \%(\mathrm{v} / \mathrm{v})$ and ammonia dosage of $60 \mathrm{wt} \%$ ) 
Table 6 lists the crystallinity values of wheat straw samples evaluated by FTIR and XRD. Both TCI and LOI were calculated based on FTIR analysis, reflecting the crystallinity changes of cellulose in wheat straw samples, while the $C r I$ values according to XRD measurement indicated the crystallinity modification of the entire wheat straw sample. Table 7 shows that both TCI and LOI of cellulose slightly increased, indicating some degradation of non-crystalline regions of cellulose after pretreatment (Li et al. 2015). However, the $\mathrm{CrI}$ of pretreated wheat straw gradually increased with the increase of the severity of AEW pretreatment. For instance, the $C r I(55.8 \%)$ of wheat straw pretreated at the optimal conditions was $25.4 \%$ higher compared to the raw material $(44.5 \%)$. The increments of $\mathrm{CrI}$ were associated with the removal of amorphous components (such as lignin, extractives) in pretreated wheat straw ( $\mathrm{Xu}$ et al. 2015), which were in good agreement with the obtained results shown in Fig. 1 and 3, as well as Tables 2 to 4.

Table 6. Crystallinity of Wheat Straw Samples Evaluated by FTIR and XRD

\begin{tabular}{|c|c|c|c|c|c|c|}
\hline Samples & Energy Input & $\begin{array}{c}\text { Ethanol } \\
\text { Concentration } \\
(\%, v / v)\end{array}$ & $\begin{array}{c}\text { Ammonia } \\
\text { Dosage } \\
(\mathrm{wt} \%)\end{array}$ & TCI & LOI & Crl (\%) \\
\hline $\mathrm{a}$ & \multicolumn{3}{|c|}{ Raw wheat straw } & 0.902 & 0.71 & 44.5 \\
\hline $\mathrm{b}$ & $150^{\circ} \mathrm{C}, 2 \mathrm{~h}$ & 55 & 60 & 0.934 & 0.75 & 47.0 \\
\hline $\mathrm{c}$ & $170^{\circ} \mathrm{C}, 2 \mathrm{~h}$ & 18 & 60 & 0.991 & 0.81 & 50.6 \\
\hline $\mathrm{d}$ & $170^{\circ} \mathrm{C}, 2 \mathrm{~h}$ & 55 & 20 & 1.080 & 0.83 & 53.2 \\
\hline $\mathrm{e}$ & $170^{\circ} \mathrm{C}, 2 \mathrm{~h}$ & 55 & 60 & 1.110 & 0.86 & 55.8 \\
\hline
\end{tabular}

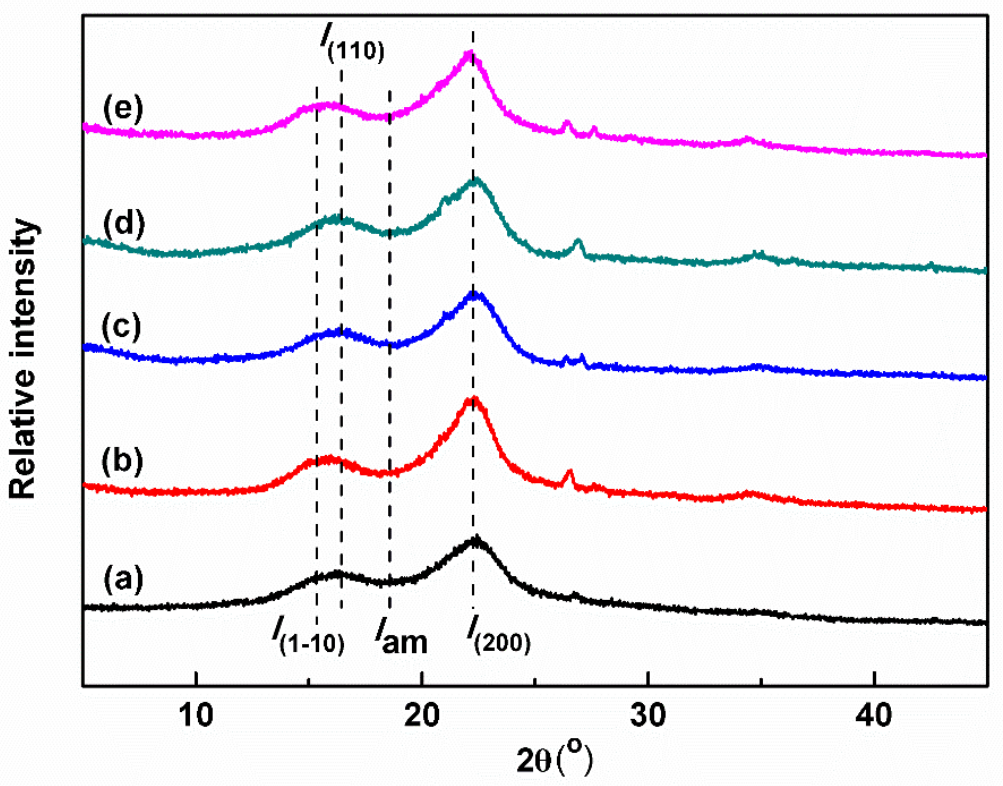

Fig. 7. XRD patterns of wheat straw before and after AEW pretreatment (a: raw material; $b$ : wheat straw pretreated at $150{ }^{\circ} \mathrm{C}$ for $2 \mathrm{~h}$ with ethanol concentration of $55 \%(\mathrm{v} / \mathrm{v})$ and ammonia dosage of $60 \mathrm{wt} \%$; c: wheat straw pretreated at $170{ }^{\circ} \mathrm{C}$ for $2 \mathrm{~h}$ with ethanol concentration of $18 \%$ $(\mathrm{v} / \mathrm{v})$ and ammonia dosage of $60 \mathrm{wt} \%$; d: wheat straw pretreated at $170{ }^{\circ} \mathrm{C}$ for $2 \mathrm{~h}$ with ethanol concentration of $55 \%(\mathrm{v} / \mathrm{v})$ and ammonia dosage of $20 \mathrm{wt} \%$; e: wheat straw pretreated at $170{ }^{\circ} \mathrm{C}$ for $2 \mathrm{~h}$ with ethanol concentration of $55 \%(\mathrm{v} / \mathrm{v})$ and ammonia dosage of $60 \mathrm{wt} \%$ ) 


\section{Characterization of SLS}

The fractionated and purified lignin from AEW pretreatment with optimal conditions was first acetylated and then used to prepare SLS. Before acetylation, lignin samples of P-lignin and D-lignin were obtained by acid precipitation and direct drying of spent liquor, respectively, after recovery of ethanol and ammonia. As tested by GPC, the molecular weights $\left(M_{\mathrm{w}}\right)$ of P-lignin and D-lignin were 4000 and 29290, respectively, and the corresponding polydispersity index values were 1.13 and 1.17 , respectively. The higher $M_{\mathrm{w}}$ of D-lignin indicated that more re-polymerization and condensation of lignin occurred in direct drying of the concentrated spent liquor.

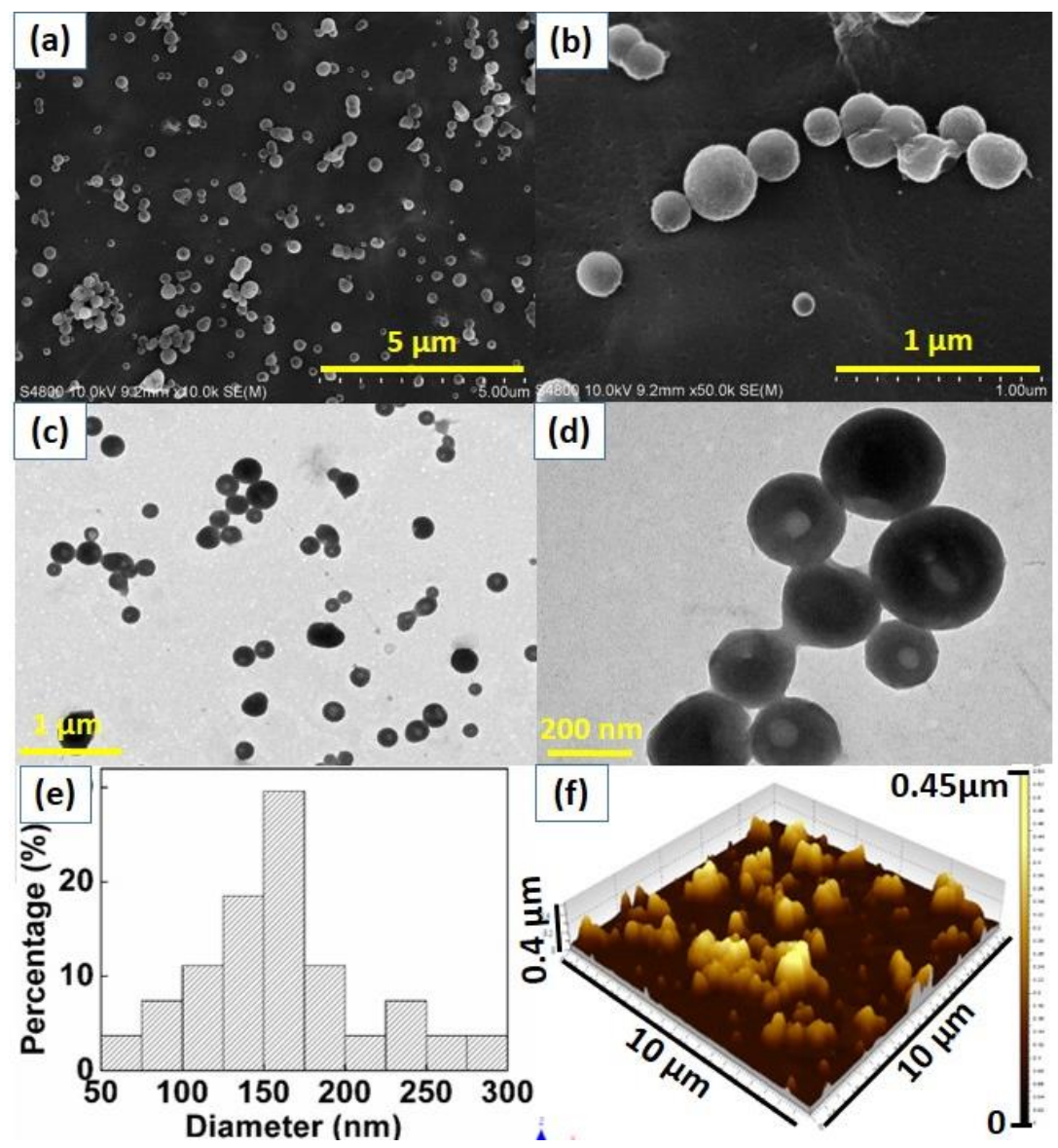

Fig. 8. Morphologies of submicron lignin spheres prepared using the lignin obtained by acid precipitation from the spent liquor derived from AEW pretreatment of wheat straw ( $a$ and $b$ : SEM images with magnifications of $10 \mathrm{k}$ and $50 \mathrm{k}$ respectively; $c$ and d: TEM images; e: Diameter distribution based on TEM analysis; f: AFM image)

The morphologies of SLS prepared using P-lignin are given in Fig. 8. As shown in Figs. 8a and c, the resulting SLS particles had good dispersibility in the mixed THF-water solution. The SLS particles showed clear boundaries, smooth surface, and spherical morphologies (Fig. 8b and c). The diameters of the SLS particles ranged from 50 to 300 $\mathrm{nm}$ and the corresponding average diameter was $161.2 \pm 53.6 \mathrm{~nm}$, based on the statistics of TEM analysis. Each SLS particle clearly exhibited a hollow structure, as displayed in Fig. 8c. But the conditions of AEW pretreatment had no clear impact on the morphologies and size of the obtained SLS by the same preparation method in this work. This was likely 
because the acid precipitation and acetylation of lignin reduced the difference of the obtained lignin samples, thus minimizing the effects of pretreatment conditions on the properties of the final SLS. More work on the structure characterization of lignin samples should be done in future. The as-prepared SLS particles with the unique structure have many potential applications, such as the carrier for the controlled release of drugs or agricultural activities (Sameni et al. 2018), the fillers in composites (Zhang et al. 2019).

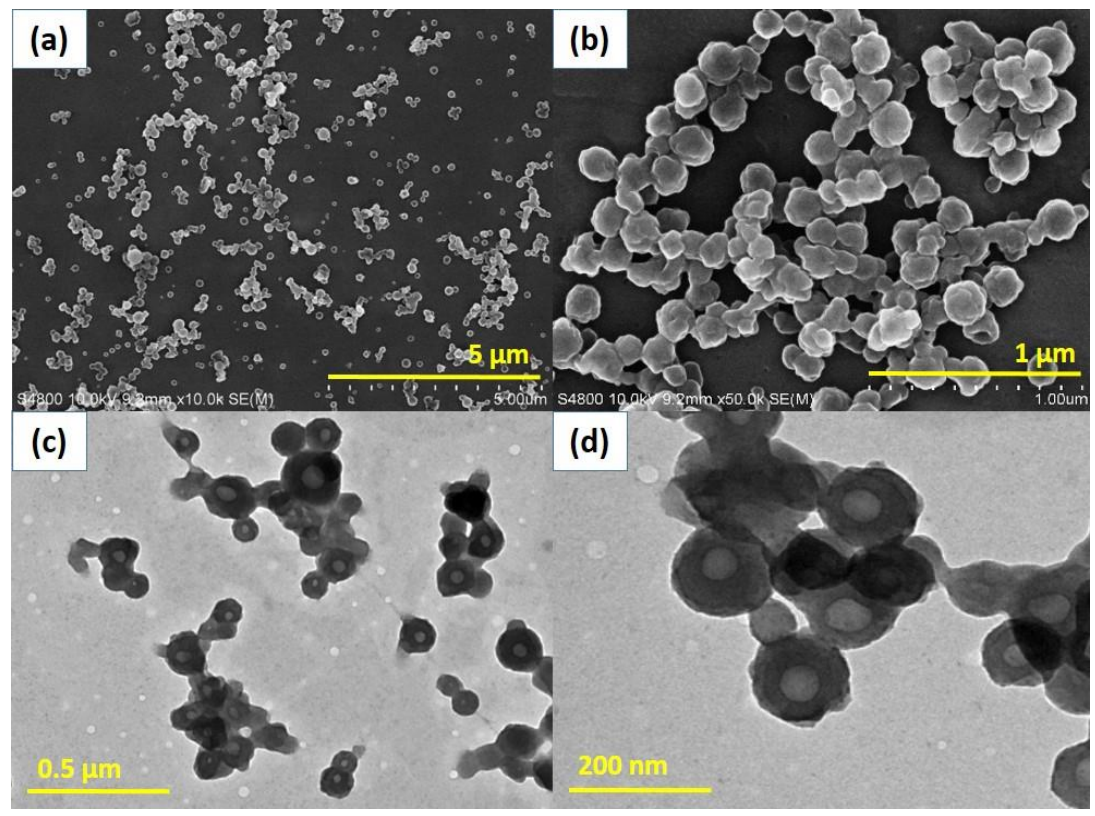

Fig. 9. Morphologies of submicron lignin spheres prepared using the lignin obtained after direct dry of spent liquor derived from AEW pretreatment of wheat straw (a and b: SEM images with magnifications of $10 \mathrm{k}$ and $50 \mathrm{k}$ respectively; $\mathrm{c}$ and $\mathrm{d}$ : TEM images)

For comparison, the SLS particles were also prepared using D-lignin. The resulting SLS particles had more uniform diameters in the range of 100 to $200 \mathrm{~nm}$ with the smaller average diameter of $134.1 \pm 43.6 \mathrm{~nm}$, but also exhibited a hollow structure (Fig. 9). However, the obtained SLS particles from D-lignin showed rougher surface and more aggregation compared to the one fabricated with P-lignin. The morphology difference of SLS is largely dependent on the nature of the obtained lignin itself (such as molecular weight, purity, and functional groups) (Zhao et al. 2016). The nonuse of acid in the fabrication of SLS is a cleaner and more sustainable process.

\section{Mass Balance}

The mass balance of AEW pretreatment under the optimal conditions and enzymatic saccharification was evaluated, as shown in Fig. 10. Pulverized wheat straw (1 $\mathrm{kg}$, oven-dried basis) was pretreated at $170{ }^{\circ} \mathrm{C}$ for $2 \mathrm{~h}$ with an ethanol concentration of $55 \%$ (v/v) and an ammonia dosage of $60 \mathrm{wt} \%$ (corresponding ammonia concentration $7.5 \mathrm{wt} \%$ ). Upon completion of AEW pretreatment, solid and liquid phases were separated, and the cellulosic solid residue (with a yield of 57.2\%) was washed to remove the extracted substances (e.g., degraded lignin, extractives) in pretreatment. The washed solid with 283 g glucan, $106 \mathrm{~g}$ xylan, $58 \mathrm{~g}$ lignin, and $12 \mathrm{~g}$ extractives was subjected to enzymatic hydrolysis. After saccharification, $404 \mathrm{~g}$ fermentable sugars (291 g glucose $+113 \mathrm{~g}$ xylose) were obtained in the hydrolyzate, and the corresponding $Y_{\text {total sugar }}$ was $81.7 \pm 0.2 \%$, which 
was comparable with the modified alkali pretreatment (80\%) with $11 \mathrm{wt} \% \mathrm{NaOH}, 2 \mathrm{wt} \%$ sodium lignosulfonate, and $0.1 \mathrm{wt} \%$ anthraquinone (Xu et al. 2015). Additionally, comparable $Y_{\text {total sugar }}(80.2 \pm 0.6 \%)$ was obtained for AEW pretreatment without washing before saccharification (Fig. 10b), although purification of hydrolyzate might be needed for the downstream process. However, AEW pretreatment does not need the high capital cost for $\mathrm{NaOH}$ recovery, because both ethanol and ammonia can be easily recovered and reused. According to the authors' experimental results, the recovery efficiencies of ethanol and ammonia were $93.7 \%$ and $85.7 \%$, respectively.

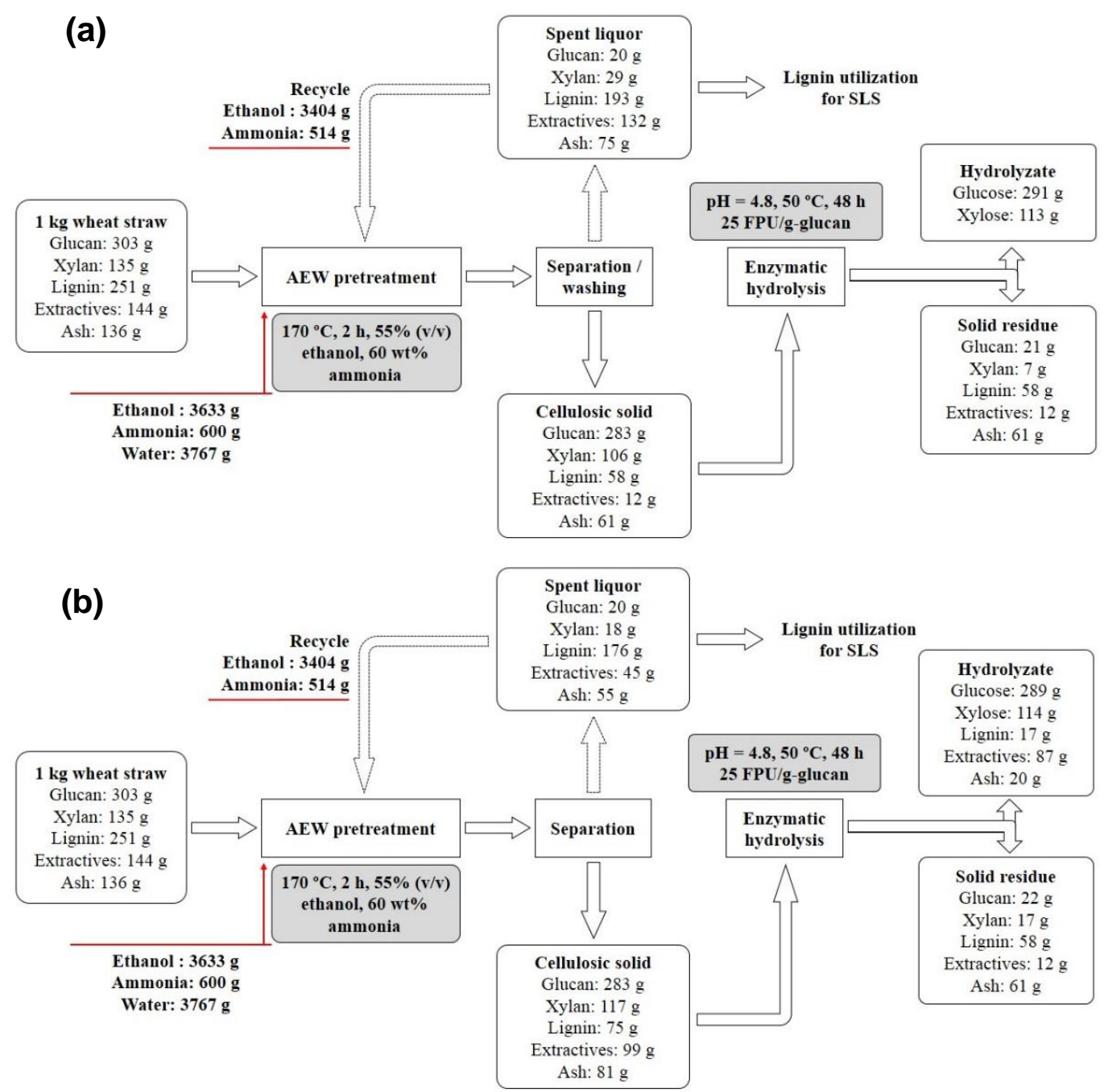

Fig. 10. Mass balance of AEW pretreatment and saccharification (a: with washing; b: without washing)

Based on the organic element analysis (Table 7), nitrogen content in the fractionated lignin was $5.2 \%$, which was obviously higher compared to raw wheat straw (approximately $0.6 \%$ ). This was because ammonia could react with lignin, causing lignin degradation via ammonolysis (Kim et al. 2003). The additional loss of approximately $9 \%$ ammonia and $6 \%$ ethanol could be further lowered in large-scale application with good sealing of equipment and efficient operation. Therefore, AEW pretreatment was a more economical and sustainable process compared to alkali-based pretreatment, particularly for 
a relatively small plant for the treatment of agricultural waste with a limited collection radius. In addition, with the concept of integrated biorefinery (Van Heiningen 2006; Jahan and $\mathrm{He} 2018$ ), the fractionated lignin can be used to prepare the high value SLS to further increase the economic feasibility of the overall process of AEW pretreatment. As for the preparation of SLS in THF, the solvent of THF can also be readily recovered by evaporation because the boiling point of THF is $66^{\circ} \mathrm{C}$. As tested in this work, the recovery of THF could be above $98 \%$.

Table 7. Organic Element Analysis of Wheat Straw Before and After AEW Pretreatment

\begin{tabular}{|c|c|c|c|c|c|}
\hline Samples & N (\%) & O (\%) & C (\%) & H (\%) & S (\%) \\
\hline Raw Materials & 0.58 & 51.09 & 42.62 & 4.90 & 0.81 \\
\hline Pretreated Wheat Straw & 0.32 & 54.43 & 39.43 & 5.00 & 0.82 \\
\hline Fractionated Lignin ${ }^{a}$ & 5.20 & 33.86 & 55.53 & 4.60 & 0.81 \\
\hline
\end{tabular}

a Purified lignin obtained by acid precipitation of spent liquor and the followed washing with deionized water

\section{CONCLUSIONS}

1. Ammonia-ethanol-water pretreatment of wheat straw was conducted and evaluated by enzymatic saccharification. Results exhibited that ammonia-ethanol-water (AEW) pretreatment is a promising approach with many advantages, such as high recovery of available carbohydrates after pretreatment as well as high lignin removal (77\%) and high extractives removal $(90 \%)$.

2. The AEW pretreatment can achieve easy recovery and reuse of chemicals and solvent (clean process), reduced water use (without washing of substrate before saccharification), and the high value utilization of the fractionated lignin.

3. The preparation of submicron lignin spheres with unique structure and average diameter of $161.2 \pm 53.6 \mathrm{~nm}$ could valorize lignin, thus further increasing the economic viability of the entire process of AEW pretreatment.

\section{ACKNOWLEDGEMENTS}

This work was financially supported by the National Natural Science Foundation of China (grant number 31870568), Shandong Provincial Natural Science Foundation for Distinguished Young Scholars (China) (grant number ZR2019JQ10), the Major Program of Shandong Province Natural Science Foundation (grant number ZR2018ZB0208), QIBEBT Research Foundation (grant number QIBEBT ZZBS 201801), and Strategic Priority Research Program of the Chinese Academy of Sciences (grant number XDA21060201). 


\section{REFERENCES CITED}

Agbor, V. B., Cicek, N., Sparling, R., Berlin, A., and Levin, D. B. (2011). "Biomass pretreatment: Fundamentals toward application," Biotechnol. Adv. 29(6), 675-685. DOI: 10.1016/j.biotechadv.2011.05.005

Chen, Q. J., Zhou, L. L., Zou, J. Q., and Gao, X. (2019). "The preparation and characterization of nanocomposite film reinforced by modified cellulose nanocrystals," Int. J. Biol. Macromol. 132, 1155-1162.

DOI: 10.1016/j.ijbiomac.2019.04.063

Ding, S. Y., Liu, Y. S., Zeng, Y., Himmel, M. E., Baker, J. O., and Bayer, E. A. (2012). "How does plant cell wall nanoscale architecture correlate with enzymatic digestibility?," Science 338(6110), 1055-1060. DOI: 10.1126/science.1227491

Ghose, T. K. (1987). "Measurement of cellulase activities," Pure Appl. Chem. 59(2), 257268. DOI: $10.1351 /$ pac198759020257

Guo, Y., Zhou, J., Wen, J., Sun, G., and Sun, Y. (2015). "Structural transformations of triploid of Populus tomentosa Carr. lignin during auto-catalyzed ethanol organosolv pretreatment," Ind. Crop. Prod. 76, 522-529. DOI: 10.1016/j.indcrop.2015.06.020

Hallac, B. B., Sannigrahi, P., Pu, Y., Ray, M., Murphy, R. J., and Ragauskas, A. J. (2010). "Effect of ethanol organosolv pretreatment on enzymatic hydrolysis of Buddleja davidii stem biomass," Ind. Eng. Chem. Res. 49(4), 1467-1472. DOI: 10.1021/ie900683q

Hashemi, S. S., Karimi, K., and Karimi, A. M. (2019). "Ethanolic ammonia pretreatment for efficient biogas production from sugarcane bagasse," Fuel 248, 196-204. DOI: 10.1016/j.fuel.2019.03.080

$\mathrm{Hu}, \mathrm{F}$., and Ragauskas, A. (2012). "Pretreatment and lignocellulosic chemistry," BioEnergy Res. 5(4), 1043-1066. DOI: 10.1007/s12155-012-9208-0

Huijgen, W. J. J., Smit, A. T., Reith, J. H., and Uil, H. D. (2011). "Catalytic organosolv fractionation of willow wood and wheat straw as pretreatment for enzymatic cellulose hydrolysis," J. Chem. Technol. Biot. 86(11), 1428-1438. DOI: 10.1002/jctb.2654

Hurtubise, F. G., and Krassig, H. (1960). "Classification of fine structural characteristics in cellulose by infrared spectroscopy. Use of potassium bromide pellet technique," Anal. Chem. 32(2), 177-181. DOI: 10.1021/ac60158a010

Jahan, M. S., and He, Z. B. (2018). "Potassium hydroxide based biorefinery concepts for nonwood bioresources," J. Bioresour. Bioprod. 3(1), 1-2. DOI:

10.21967/jbb.v3i1.165

Jing, X., Zhang, X., and Bao, J. (2009). "Inhibition performance of lignocellulose degradation products on industrial cellulase enzymes during cellulose hydrolysis," Appl. Biochem. Biotechnol. 159(3), 696-707. DOI: 10.1007/s12010-009-8525-Z

Kim, T. H., Kim, J. S., Sunwoo, C., and Lee, Y. Y. (2003). "Pretreatment of corn stover by aqueous ammonia," Bioresource Technol. 90(1), 39-47. DOI: 10.1016/s09608524(03)00097-X

Li, B., Liu, C., Yu, G., Zhang, Y., Wang, H., Mu, X., and Peng, H. (2017). "Recent progress on the pretreatment and fractionation of lignocelluloses for biorefinery at QIBEBT,” J. Bioresour. Bioprod. 2(1), 4-9. DOI: 10.21967/jbb.v2i1.67

Li, B., Xu, W., Kronlund, D., Määttänen, A., Liu, J., Smått, J. H., Peltonen, J., Willför, S., Mu, X., and Xu, C. (2015). "Cellulose nanocrystals prepared via formic acid hydrolysis followed by TEMPO-mediated oxidation," Carbohydr. Polym. 133, 605612. DOI: 10.1016/j.carbpol.2015.07.033 
Li, M. F., Yang, S., and Sun, R. C. (2016). "Recent advances in alcohol and organic acid fractionation of lignocellulosic biomass," Bioresource Technol. 200, 971-980. DOI: 10.1016/j.biortech.2015.10.004

Liu, C., Heide, E. V. D., Wang, H., Li, B., Yu, G., and Mu, X. (2013). "Alkaline twinscrew extrusion pretreatment for fermentable sugar production," Biotechnol. Biofuels 6(1), Article number 97. DOI: 10.1186/1754-6834-6-97

Liu, X., Wei, W., and Wu, S. (2019). "Synergism of organic acid and deep eutectic solvents pretreatment for the co-production of oligosaccharides and enhancing enzymatic saccharification," Bioresource Technol. 290, Article ID 121775. DOI: 10.1016/j.biortech.2019.121775

Liu, Y. J., Li, B., Feng, Y., and Cui, Q. (2020). “Consolidated bio-saccharification: Leading lignocellulose bioconversion into the real work," Biotechnol. Adv. 40, Article ID 107535. DOI: 10.1016/j.biotechadv.2020.107535

Luo, X., Li, Y., Gupa, N. K., Sels, B., Ralph, J., and Shuai, L. (2020). "Protection strategies enable selective conversion of biomass," Angew. Chem. Int. Ed. Engl. (Accepted). DOI: 10.1002/anie.201914703

Luo, X., Zhu, J. Y., Gleisner, R., and Zhan, H. Y. (2011). "Effect of wet-pressinginduced fiber hornification on enzymatic saccharification of lignocelluloses," Cellulose 18(4), 1055-1062. DOI: 10.1007/s10570-011-9541-z

Mei, X., Liu, J., Peng, F., and Sun, R. (2020). "Phosphoric acid-assisted pretreatment strategy for the rational synthesis of lignin-derived hierarchical porous carbon toward high-performance supercapacitors," Pap. Biomater. 5(1), 43-53. DOI: 10.12103/j.issn.2096-2355.2020.01.005

Mesa, L., González, E., Cara, C., González, M., Castro, E., and Mussatto, S. I. (2011). "The effect of organosolv pretreatment variables on enzymatic hydrolysis of sugarcane bagasse," Chem. Eng. J. 168(3), 1157-1162. DOI: 10.1016/j.cej.2011.02.003

Mosier, N., Wyman, C., Dale, B., Elander, R., Lee, Y. Y., Holtzapple, M., and Ladisch, M. (2005). "Features of promising technologies for pretreatment of lignocellulosic biomass," Bioresource Technol. 96(6), 673-686. DOI: 10.1016/j.biortech.2004.06.025

Nair, S. S., Sharma, S., Pu, Y., Sun, Q., Pan, S., Zhu, J. Y., Deng, Y., and Ragauskas, A. J. (2014). "High shear homogenization of lignin to nanolignin and thermal stability of nanolignin-polyvinyl alcohol blends," ChemSusChem 7(12), 3513-3520. DOI: $10.1002 /$ cssc. 201402314

Nelson, M. L., and O'Connor, R. T. (1964). "Relation of certain infrared bands to cellulose crystallinity and crystal lattice type. Part II. A new infrared ratio for estimation of crystallinity in celluloses I and II," J. Appl. Polym. Sci. 8(3), 1325-1341. DOI: 10.1002/app.1964.070080323

Ni, Y., and Hu, Q. (1995). “Alcell lignin solubility in ethanol-water mixtures," J. Appl. Polym. Sci. 57(12), 1441-1446. DOI: 10.1002/app.1995.070571203

Park, J. K., and Phillips, J. A. (1988). “Ammonia catalyzed organosolv delignification of poplar," Chem. Eng. Commun. 65(1), 187-205. DOI: 10.1080/00986448808940253

Qian, Y., Deng, Y., Qiu, X., Li, H., and Yang, D. (2014). "Formation of uniform colloidal spheres from lignin, renewable resources recovered from pulping spent liquor," Green Chem. 16(4), 2156-2163. DOI: 10.1039/C3GC42131G

Sameni, J., Krigstin, S., Jaffer, S. A., and Sain, M. (2018). "Preparation and characterization of biobased microspheres from lignin sources," Ind. Crop. Prod. 117, 58-65. DOI: 10.1016/j.indcrop.2018.02.078 
Segal, L., Creely, J. J., Martin, Jr., A. E., and Conrad, C. M. (1959). “An empirical method for estimating the degree of crystallinity of native cellulose using the X-ray diffractometer," Text. Res. J. 29(10), 786-794. DOI: 10.1177/004051755902901003

Selig, M., Weiss, N., and Ji, Y. (2008). Enzymatic Saccharification of Lignocellulosic Biomass (NREL/TP-510-42629), National Renewable Energy Laboratory, Golden, CO, USA.

Sidiras, D., and Koukios, E. (2004). "Simulation of acid-catalysed organosolv fractionation of wheat straw," Bioresource Technol. 94(1), 91-98. DOI: 10.1016/j.biortech.2003.10.029

Sixta, H. (2006). Handbook of Pulp, Wiley-VCH Verlag GmbH \& Co. KGaA, Weinheim, Germany.

Sluiter, A., Hames, B., Ruiz, R., Scarlata, C., Sluiter, J., Templeton, D., and Crocker, D. (2008). Determination of Structural Carbohydrates and Lignin in Biomass (NREL/TP-510-42618), National Renewable Energy Laboratory, Golden, CO, USA.

Sun, R. C., and Sun, X. F. (2001). "Identification and quantitation of lipophilic extractives from wheat straw," Ind. Crop. Prod. 14(1), 51-64. DOI: 10.1016/S09266690(00)00088-1

Sun, S., Sun, S., Cao, X., and Sun R. (2016). "The role of pretreatment in improving the enzymatic hydrolysis of lignocellulosic materials," Bioresource Technol. 199, 49-58. DOI: 10.1016/j.biortech.2015.08.061

Tang, C., Shan, J., Chen, Y., Zhong, L., Shen, T., Zhu, C., and Ying, H. (2017). "Organic amine catalytic organosolv pretreatment of corn stover for enzymatic saccharification and high quality lignin," Bioresource Technol. 232, 222-228. DOI: 10.1016/j.biortech.2017.02.041

Tarasov, D., Leitch, M., and Fatehi, P. (2018). "Flow through autohydrolysis of spruce wood chips and lignin carbohydrate complex formation," Cellulose 25, 1377-1393. DOI: $10.1007 / \mathrm{s} 10570-017-1643-9$

Van Heiningen, A. R. P. (2006). "Converting a kraft pulp mill into an integrated forest biorefinery," Pulp Pap. Can. 107(6), 38-43.

Vergara, P., Ladero, M., García-Ochoa, F., and Villar, J. C. (2018). "Pre-treatment of corn stover, Cynara cardunculus L. stems and wheat straw by ethanol-water and diluted sulfuric acid: Comparison under different energy input conditions," Bioresource Technol. 270, 449-456. DOI: 10.1016/j.biortech.2018.09.058

Vroom, K. E. (1957). "The "H" factor: A means of expressing cooking times and temperatures as a single variable," Pulp Pap. Mag. Can. 58(3), 228-231.

Wen, J.-L., Xue, B.-L., Sun, S.-L., and Sun, R.C. (2013). "Quantitative structure characterization and thermal properties of birch lignins after auto-catalyzed organosolv pretreatment and enzymatic hydrolysis," J. Chem. Technol. Biot. 88, 1663-1671. DOI: 10.1002/jctb.4017.

Xie, X., Feng, X., Chi, S., Zhang, Y., Yu, G., Liu, C., Li, Z., Li, B., and Peng, H. (2018). "A sustainable and effective potassium hydroxide pretreatment of wheat straw for the production of fermentable sugars," Bioresource Technol. Rep. 3, 169-176. DOI: 10.1016/j.biteb.2018.07.014

Xu, H., Che, X., Ding, Y., Kong, Y., Li, B., and Tian, W. (2019). "Effect of crystallinity on pretreatment and enzymatic hydrolysis of lignocellulosic biomass based on multivariate analysis," Bioresource Technol. 279, 271-280. DOI: 10.1016/j.biortech.2018.12.096 
Xu, H., Li, B., and Mu, X. (2016). "Review of alkali-based pretreatment to enhance enzymatic saccharification for lignocellulosic biomass conversion," Ind. Eng. Chem. Res. 55(32), 8691-8705. DOI: 10.1021/acs.iecr.6b01907

Xu, H., Yu, G., Mu, X., Zhang, C., DeRoussel, P., Liu, C., Li, B., and Wang, H. (2015). "Effect and characterization of sodium lignosulfonate on alkali pretreatment for enhancing enzymatic saccharification of corn stover," Ind. Crop. Prod. 76, 638-646. DOI: 10.1016/j.indcrop.2015.07.057

Yang, L., Cao, J., Mao, J., and Jin, Y. (2013). "Sodium carbonate-sodium sulfite pretreatment for improving the enzymatic hydrolysis of rice straw," Ind. Crop. Prod. 43, 711-717. DOI: 10.1016/j.indcrop.2012.08.027

Yuan, Z., Wen, Y., Kapu, N. S., and Beatson, R. (2018). "Evaluation of an organosolvbased biorefinery process to fractionate wheat straw into ethanol and co-products," Ind. Crop. Prod. 121, 294-302. DOI: 10.1016/j.indcrop.2018.05.028

Zhang, H. D., Fan, M. S., Li, X., Zhang, A. P., and Xie, J. (2018). "Enhancing enzymatic hydrolysis of sugarcane bagasse by ferric chloride catalyzed organosolv pretreatment and Tween 80," Bioresource Technol. 258, 295-301. DOI: 10.1016/j.biortech.2018.03.004

Zhang, Y., Xu, W., Wang, X., Ni, S., Rosqvist, E., Smått, J. H., Peltonen, J., Hou, Q., Qin, M., Willför, S., et al. (2019). "From biomass to nanomaterials: A green procedure for preparation of holistic bamboo multifunctional nanocomposites based on formic acid rapid fractionation," ACS Sustain. Chem. Eng. 7(7), 6592-6600. DOI: 10.1021/acssuschemeng.8b05502

Zhao, W., Simmons, B., Singh, S., Ragauskas, A., and Cheng, G. (2016). "From lignin association to nano-/micro-particle preparation: Extracting higher value of lignin," Green Chem. 18(21), 5693-5700. DOI: 10.1039/C6GC01813K

Zhou, Z., Lei, F., Li, P., and Jiang, J. (2018). "Lignocellulosic biomass to biofuels and biochemical: A comprehensive review with a focus on ethanol organosolv pretreatment technology," Biotechnol. Bioeng. 115(11), 2683-2702. DOI: 10.1002/bit.26788

Zhu, H., Luo, W., Ciesielski, P. N., Fang, Z., Zhu, J. Y., Henriksson, G., Himmel, M. E., and Hu, L. (2016). "Wood-derived materials for green electronics, biological devices, and energy applications," Chem. Rev. 116(16), 9305-9374. DOI:

10.1021/acs.chemrev.6b00225

Article submitted: March 20, 2020; Peer review completed: May 3, 2020; Revised version received and accepted: May 10, 2020; Published: May 14, 2020.

DOI: 10.15376/biores. 15.3.5087-5109 